\title{
The NEW GAY AND LeSbIAN PARTNERSHIPS LAW IN GERMANY
}

\author{
GREG TAYLOR*
}

This article explores the recently-enacted German registered partnerships law: An Act To End Discrimination Against Same-Sex Partnerships. The author first considers the range of options open to a legislature wishing to recognize same-sex partnerships. The author then critically and thoroughly analyzes the legislation: he gives a brief history of the political developments leading to the legislation and the important effect of these developments on shaping the Act as it came into force on 1 August 2001; provides timely legal commentary on controversial provisions and omissions of the Act; and contrasts the legislation with Alberta's Adult Interdependent Relationships Act. The various constitutional challenges to the Act, and the German Federal Constitutional Court's response to these arguments are explored, with some discussion of the possible implication of the German issues to the Canadian situation.
Cet article examine la loi allemande sur les unions enregistrées que l'on vient d'adopter: An Act To End Discrimination Against Same-Sex Partnerships (Loi visant à mettre fin à la discrimination à l'égard des unions de partenaires de même sexe). L'auteur se penche d'abord sur une gamme de possibilités mise à la disposition d'une législature voulant reconnaître les relations de même sexe. Ensuite, l'auteur donne une analyse critique et approfondie, à savoir un bref historique des développements politiques qui ont abouti à cette législation ainsi que les incidences importantes de ces développements sur l'évolution de la Loi entrée en vigueur le Irr août 2001. Il donne un commentaire juridique opportun sur les dispositions controversées et les omissions de la Loi et compare cette législation à la Adult Interdependent Relationships Act de l'Alberta. Les divers défis constitutionnels de cette loi et la réaction de la Cour constitutionnelle fédérale allemande à ces arguments sont examinés ainsi que l'implication éventuelle des questions allemandes sur la situation au Canada.

\section{TABLE OF CONTENTS}

I. INTRODUCTION ............................... 574

II. HOMOSEXUALITY IN THE CASE LAW OF THE GERMAN

FEDERAl Constitutional Court . . . . . . . . . . . . . . . . 579

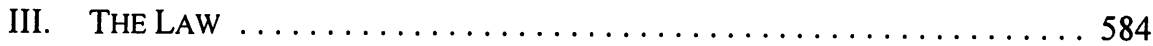

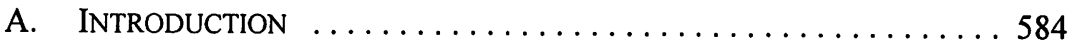

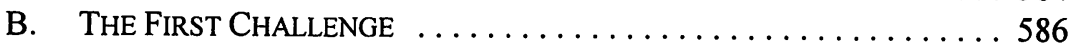

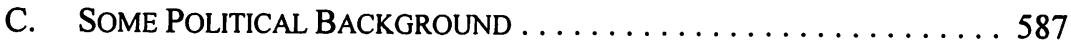

D. FORMATION OF A REGISTERED PARTNERSHIP . . . . . . . . . . . 589

E. RIGHTS AND DUTIES . . . . . . . . . . . . . . . . . . . . . . 594

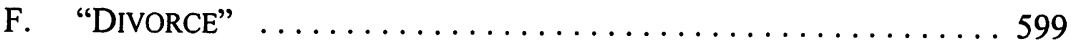

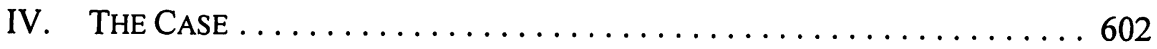

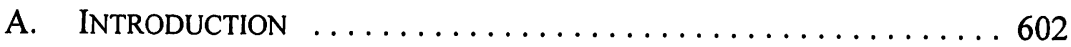

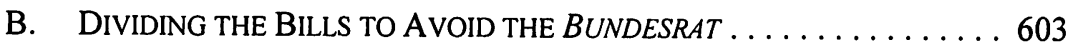

C. AMENDMENTS TO THE LAW AFTER ITS

APPROVAL BY PARLIAMENT . . . . . . . . . . . . . . . 604

Lecturer, Faculty of Law, Monash University; formerly Lecturer, School of Law, University of Adelaide. The author wishes to thank Herr Dr. Meyer of the Federal Ministry of Justice (Berlin), Laura Grenfell, Frau Rechtsanwaltin Dr. Sabine Pittrof and Herr ass. iur. Toni Esposito for their assistance in the preparation of this article. Special thanks are due to the editorial staff of the Alberta Law Review and, in particular, Sharon Roberts. The author also acknowledges that the research in Germany was conducted during a period of Special Studies Leave provided by the University of Adelaide. German law was available until the end of November 2002. 
D. Protection of MARriage: Article 6(1)

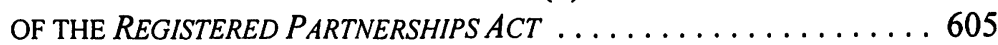

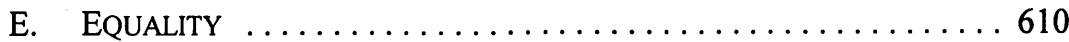

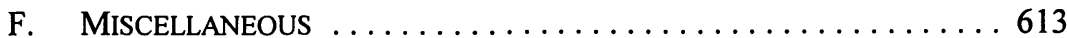

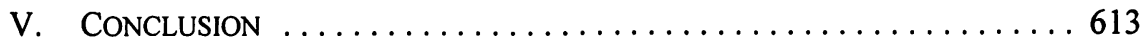

\section{INTRODUCTION}

The decision of the Ontario Court of Appeal in Halpern v. Canada (A.G.)' requiring that marriage be immediately opened to same-sex unions is the most important of all recent Canadian case law on the topic. ${ }^{2}$ Independently of the decision, Alberta enacted the Adult Interdependent Relationships $A c t,{ }^{3}$ which recognizes certain same-sex relationships within the province, but falls short of granting permission to marry. It is safe to assume that extensive commentary on emerging Canadian case law and legislation will appear in Canadian legal journals. This article provides a perspective that is probably not available in that commentary: that of German law.

What makes the recently-enacted German law on same-sex partnerships worthy of further study is not merely that it applies in the most populous country in the European Union (and thus, at least potentially, to more people than any other similar law). Rather, it is that it has generated a great deal of discussion, ${ }^{4}$ sometimes quite heated, ${ }^{5}$ not just within the usual public fora but also among constitutional lawyers with many ${ }^{6}$ commentators believing it to be unconstitutional. ${ }^{7}$ However, the Federal Constitutional Court of Germany held the law to

(2003), 225 D.L.R. (4th) 529 (Ont. C.A.) [Halpern].

For another recent Canadian case containing references to earlier case law, see EGALE Canada v. Canada (A.G.) (2003) 225 D.L.R. (4th) 472 (B.C.C.A.). For analysis of Canadian case law and further references, see Jo-Anne Pickel, "Judicial Analysis Frozen in Time: EGALE Canada v. Canada (Attorney General)" (2002) 65 Sask. L. Rev. 243. See further Bruce MacDougall, "The Celebration of Same-Sex Marriage" (2001) 32 Ottawa L. Rev. 235 at $240 \mathrm{ff}$.

$3 \quad$ S.A. 2002, c. A-4.5 [Interdependent Relationships Act].

4

J. Braun, Ehe und Familie am Scheideweg: eine Kritik des sogenannten Lebenspartnerschaftsgesetzes (Regensburg: S. Roderer, 2002) at 121 ["Familie"] complains of a "flood of literature" explaining and defending the new German law. Those opposed have not retreated into silence either, as indicated by Professor Braun's book and articles.

P. Finger, "Die registrierte Partnerschaft - Überblick über die Neuregelung und kritische Bestandsaufnahme" [2001] Monatsschrift für deutsches Recht 199 at 199, n. 2; M. Sachs, "Rechtsformliche Lebenspartnerschaften fur Menschen gleichen Geschlechts: Verfassungsgebot oder Verfassungsverstoß?" [2001] Juristische Rundschau 45 at 49; Stephan Stuber, "Gleichstellung homosexueller Lebensgemeinschaften als "Eingetragene Lebenspartnerschaft" mit der Ehe verfassungsgemäß?" [2000] Kritische Justiz 594 at 594 ["Gleichstellung"]; H. Trimbach, "Das Lebenspartnerschaftsgesetz" [2001] Neue Justiz 399 at 399; A. Zimmermann, "Gleichgeschlechtliche Lebenspartnerschaften und das Grundgesetz" in H.-J. Cremer et al., eds., Tradition und Weltoffenheit des Rechts: Festschrift für Helmut Steinberger (Berlin: Springer, 2002) 645 at 645. Note, too, the tone of argument adopted in Braun, supra note 4; J. Braun, “'Ein neues familienrechtliches Institut': zum Inkraftreten des Lebenspartnerschaftsgesetzes" [2002] Juristenzeitung 23 ["Ein neues"]; J. Braun, "Schlußwort" [2002] Juristenzeitung 294.

6 A. Klein, "Für die Verfassungskonformităt des Lebenspartnerschaftsgesetzes" [2001] Familie, Partnerschaft, Recht 434 at 434.

7 A constitutional challenge to the equivalent legislation in France was also conducted and also failed. The judgment of the Constitutional Council is dealt with in [2000] Deutsches und europarisches Familienrecht 55. However, the French case seems to have been of less interest than the German one, owing to the more numerous lines of attack offered by the German Constitution. 
be constitutional by the narrow margin of five votes to three on $17 \mathrm{July} 2002 .^{8}$ In upholding the law, it rejected arguments to the effect that the law had not been enacted in accordance with the proper procedures (which are intended, among other things, to safeguard the federal system) and - even more interestingly - that it conflicted with the human rights provisions of the German Constitution (the Basic Law). ${ }^{9}$ What objections, we might ask ourselves, could one possibly raise against the enactment of such an apparently "progressive" law under the banner of human rights? As we shall see, there were essentially two major objections: first, the law, by setting a different regime for same-sex unions from that available to other unions, violated the guarantee of equality before the law (Art. 3 of the Basic Law); second, that it detracted from the special status granted by the Basic Law to marriage and the family (Art. $6(1)$ ). The resulting jurisprudence stemming from these objections is of inherent interest to those concerned with the topic.

It is also of some practical interest in Canada, given the considerable degree of confusion and overlap that may be caused by the Halpern ruling that federal law must be read so as to permit same-sex marriage, possible statutory amendments associated with the Prime Minister's announcement on 17 June 2003 that federal legislation will be proposed to recognize same-sex unions, ${ }^{10}$ the complex interplay of federal and provincial jurisdiction over marriage under ss. 91(26) and 92(12) of the Constitution Act, $1867^{\prime \prime}$ and the existence of prior provincial statutes such as Alberta's Adult Interdependent Relationships Act. ${ }^{12}$ These challenges raise questions related to federalism and the Canadian Charter of Rights and Freedoms ${ }^{13}$ that are somewhat similar to those recently considered by the German Federal Constitutional Court.

Of course, Germany is not the first country in Europe ${ }^{14}$ to introduce a law permitting gay and lesbian partners to have their partnership recognized in some form by the state. ${ }^{15}$ Such

Extended extracts from the judgment are reprinted in [2002] Neue Juristische Wochenschrift 2543 ["The Judgment"] pending its appearance in the official law reports. This occurred just as this article was going to press ((2002) 105 BVerfGE 313), but in the time available, no attempt could be made to convert the references below. Like almost all German cases, the names of the plaintiff and defendant are not used in citing the case. A reference to what was then the forthcoming challenge to the law may be found in Roland Schimmel \& Stefanie Heun, "The Legal Situation of Same-Sex Partnerships in Germany: An Overview" in Robert Wintemute \& Mads Andenæs, eds., Legal Recognition of Same-Sex Partnerships: A Study of National, European and International Law (Oxford: Hart, 2001) 575 at 590. Commonly referred to as The Basic Law (Grundgesetz): The Constitution of the Federal Republic of Germany, 23 May 1999, as amended numerous times; available online: Jurisprudentia <www. jurisprudentia.de/index.html> [Basic Law].

See online: Website of the Prime Minister of Canada $<w w w . p m . g c . c a /$ default.asp? Language $=E \&$ Page $=$ newsroom $\&$ Sub $=$ newsreleases $\& D o c=$ samesexunions .20030617 e.htm $>$. (U.K.), 30 \& 31 Vict., c. 3, reprinted in R.S.C. 1985, App. II., No. 5.

Interdependent Relationships Act, supra note 3.

Part I of the Constitution Act, 1982, being Schedule B to the Canada Act 1982 (U.K.), 1982, c. 11. However, not all countries in the European Union, let alone the world, have introduced such legislation, which may lead to difficulties if one or both of the parties to a state-recognized partnership move to a country that has no such legislation: see D. Jakob, "Die eingetragene Lebenspartnerschaft im Europarecht" [2002] Zeitschrift für das gesamte Familienrecht 501 at 502; P. Nygh, "The Consequences for Australia of the New Netherlands Law Permitting Same-Gender Marriages" (2002) 16 Austl. J. Fam. L. 139.

is A collection of news items relating to gay and lesbian partnership laws throughout the world may be found online: GayLawNet $<w w w$.gaylawnet.com $/$ news $/ 2003 /$ ne_part. $h t m>$. No attempt was made to survey this material for the purposes of this article. 
a measure has been in place now for several years in the Scandinavian countries, ${ }^{16}$ whose lead was followed to some extent in France ${ }^{17}$ and parts of Spain and Italy.$^{18}$ Similar legislation has been proposed by the Labour Party in England.$^{19}$ Holland has recently gone one step further: having begun with a law creating a separate legal institution of partnership for homosexuals, it now permits them to marry each other in the same way as heterosexuals marry. ${ }^{20}$ Newspaper reports indicated that a similar step had just been taken in Belgium as this article was prepared for publication. ${ }^{21}$ Even in the United States, which has seen more than its fair share of setbacks to this cause, the State of Vermont recently enacted a law granting

On the situation in Denmark, see the Danish law of 7 June 1989 reprinted in [2000] Deutsches und europäisches Familienrecht 50; Peter Dopffel \& Jens Scherpe, "Gleichgeschlechtliche Lebensgemeinschaften im Recht der nordischen Lander" in J. Basedow et al., eds., Die Rechtsstellung gleichgeschlechtlicher Lebensgemeinschaften (Tubingen: Mohr Siebeck, 2000) 7 at 10-13; Ingrid Lund-Andersen, "The Danish Registered Partnership Act, 1989: Has the Act Meant a Change in Attitudes?" in Wintemute \& Andenæs, supra note 8, 417 at 417; G. Ring \& L. Olsen-Ring, "Dänemarks Vorreiterrolle bei der Etablierung des Instituts einer registrierten (Lebens-) Partnerschaft in Europa" [1999] Zeitschrift fur Rechtspolitik 459; J. Risse, Der verfassungsrechtliche Schutz von Homosexualität (Baden Baden: Nomos, 1998) at 30; Jens Scherpe, "Zehn Jahre registrierte Partnerschaft in Dănemark: Zur Novellierung des Gesetzes von 1989" [2000] Deutsches und europäisches Familienrecht 32 ["Zehn Jahre"]; Jens Scherpe, "Erfahrungen mit dem Rechtsinstitut der registrierten Partnerschaft in Dänemark" [2001] Familie, Partnerschaft, Recht 439 ["Erfahrungen"]; A. Wacke, "Die Registrierung homosexueller Partnerschaften in Dănemark" [1990] Zeitschrift für das gesamte Familienrecht 347. On the Scandinavian countries in general, see Manfred Bruns, "Art. 6(1)GG und gesetzliche Regelungen für gleichgeschlechtliche Lebensgemeinschaften" [1996] Zeitschrift für Rechtspolitik 6 at 6 ["Art. 6(1)GG"]; Dopffel \& Scherpe, above at 13; C. Christensen, "If Not Marriage? On Securing Gay and Lesbian Family Values by a 'Simulacrum of Marriage"" (1998) 66 Fordham L. Rev. 1699 at $1744 \mathrm{ff}$; Risse, ibid. at 30; Scherpe, "Zehn Jahre," ibid. at 34.

By the introduction of Title XII into Book 1 of the Civil Code, reprinted in French in [2000] Deutsches und europarisches Familienrecht 48 and in German in [2000] Zeitschrift für das gesamte Familienrecht 531. See further Daniel Borrillo, "The "Pacte Civil de Solidarité" in France: Midway Between Marriage and Cohabitation" in Wintemute \& Andenæs, supra note 8, 475 at 488; Dopffel \& Kötz, "Einleitung" in J. Basedow et al., eds., supra note 16,1 at 2; F. Ferrand, "Die Rechtsstellung gleichgeschlechtlicher Partnerschaften in Frankreich" in Basedow et al., supra note 16; J. Hauser, "Nichteheliche Lebensgemeinschaften in Frankreich: Der "Pacte Civil de Solidarité" (PACS) nach dem Gesetz Nr. 99944 vom 15. November 1999" [2000] Deutsches und europäisches Familienrecht 29; W. Schluter, J. Heckes \& S. Stommel, "Die gesetzliche Regelung von außerehelichen Partnerschaften gleichen und verschiedenen Geschlechts im Ausland und die deutschen Reformvorhaben" [2000] Deutsches und europaisches Familienrecht 1 at $2 \mathrm{ff} ; \mathrm{C}$. Schreiber, "Erfahrungen mit Lebenspartnerschaften am Beispiel Frankreichs" [2001] Familie, Partnerschaft, Recht 442.

Francesc Jaurena I Salas, "The Law on Stable Unions of Couples in the Catalonia Autonomous Community of Spain" in Wintemute \& Andenæs, supra note 8, 505 at c. 27; Risse, supra note 16 at 30.

19 The Labour Party's web site states that "under plans for legally recognised civil partnerships to be set out in summer 2003, lesbians and gay men would be granted many of the same rights as married couples" (Labour Party, "What is Labour doing for ... lesbians and gay men?" (June 2003), online: Labour Party <www.labour.org.uk/forlesbiansandgaymen/>) On this proposal, see P. Tatchell, "Unfair to Everybody!" New Statesman 15:737 (16-30 December 2002) 16.

K. Boele-Woelki \& W. Schrama, "Die Rechtsstellung von Menschen mit homosexueller Veranlagung im niederländischen Recht" in Basedow et al., supra note 16 at 59-108; B. Eggen, "Gleichgeschlechtliche Lebensgemeinschaften - Kontinuităt im Wandel intimer und familiärer Lebensformen" [2001] Familie, Partnerschaft, Recht 444 at 447; Nygh, supra note 14; Schlüter, Heckes \& Stommel, supra note 17 at 4; B. Verschraegen, "Gleichgeschlechtliche Beziehungen im Spiegel des Rechts" [2000] Deutsches und europaisches Familienrecht 64 at 66ff; Kees Waaldijk, "Small Change: How the Road to Same-Sex Marriage Got Paved in the Netherlands" in Wintemute \& Andenæs, supra note 8,437 at c. 23 .

21 See online: Stonewall <www.stonewall.org.uk/stonewall/news/belgium_marriage.html $>$. 
homosexual unions a considerable degree of recognition by the state. ${ }^{22}$ However, none of the aforementioned countries has a federal system quite like that in Canada.

To understand the objections to the German legislation, it is first necessary to describe the provisions of the impugned law, and to assess their effect and effectiveness. As the European experience has shown, a legislature wishing to enact a law recognizing the existence of partnerships between gays and lesbians has a number of models from which to choose. Specifically, a state may: $:^{23}$

- $\quad$ simply declare that marriage, in the traditional sense of the word, may be contracted between members of the same sex (the "gay marriage" model).

enact a general law applying to all partners, whether of the same-sex or of different sexes, who are not and, in the case of heterosexuals, presumably do not wish to be married - yet who may submit to a state-authorized procedure falling short of marriage for recognizing their partnership (the general registered partnerships model). Within this variant, the state may determine the extent to which the rights and duties associated with marriage apply to registered partnerships. It may stipulate that there be an intimate or other relationship between the parties, or it may open the law to all unmarried persons. ${ }^{24}$ Restricting registration to parties who are not closely related to each other may indicate that some manner of intimate relationship is expected to exist between the parties. Consequently, this variant excludes close relatives who live together and care for each other without a sexual relationship.

- enact a law similar to that outlined in the preceding paragraph (and with the same choice of sub-options), but restricted to same-sex partners only (the same-sex registered partnerships model).

- choose any of the above options, but open registration to groups of more than two people (the multi-person variant).

- dispense with registration and the associated need to opt in, and instead associate rights and duties similar to those of marriage with the factual existence of a partnership (the full de facto model).

entirely dispense with the idea of recognizing partnerships as such (apart from marriage), but change other laws so that some of the benefits available to married

This followed the interesting case of Baker v. Vermont, 744 A.2d 864 (1999) (Vt. Sup. Ct.). See further Robin Cheryl Miller, "Marriage between Persons of Same Sex" (2000) 81 A.L.R. (5th) 1, which contains a wealth of other references, and also Christensen, supra note 16 at $1739 \mathrm{ff} ; \mathrm{H}$. Krause, "Marriage for the New Millennium: Heterosexual, Same Sex — or Not at All?" [2000] Deutsches und europäisches Familienrecht 208 at $212 \mathrm{ff}$; T. Lundmark, "Homosexuelle Partnerschaften in den U.S.A.: Die Einfuhrung der Civil Union fur gleichgeschlechtliche Paare im U.S.-Bundesstaat Vermont und deren Bedeutung furr das Bundesrecht" [2000] Deutsches und europäisches Familienrecht 236; Cass Sunstein, Designing Democracy: What Constitutions Do (New York: Oxford University Press, 2001) at c. 8.

2.3 Rebecca Bailey-Harris, "Same-Sex Partnerships in English Family Law" in Wintemute \& Andenæs, supra note 8, 605 at $618 \mathrm{ff}$; K. Muscheler, Das Recht der eingetragenen Lebenspartnerschaften: Begründung - Rechtsfolgen - Aufhebung - Faktische Partnerschaft (Berlin: Erich Schmidt, 2001) at 24-27; Verschraegen, supra note 20 at $68,74$. 
couples are also available to those actually living together in a partnership (the partial de facto model). This can be a step along the way to a full de facto model.

As far as the author is aware, no Western country has chosen the multi-person variant. Later, however, we shall see that an omission in the drafting of the German legislation leaves open the argument that it has been adopted in Germany. Nevertheless, the other models have appeared in a number of Western countries: Holland recently adopted the "gay marriage" model; some form of the general registered partnerships model was adopted in France and Belgium; ${ }^{25}$ the Scandinavian countries have generally adopted the same-sex registered partnerships model; ${ }^{26}$ and, it has been said, "Australian States were the forerunners among common-law jurisdictions to enact statutes regulating cohabitation" ${ }^{27}$ along de facto lines ${ }^{28}$ (the New South Wales and the Australian Capital Territory's legislation being specifically mentioned in a German study as examples of particularly thoroughgoing legislative reforms). ${ }^{29}$

Alberta chose a mixed model: s. 3(1) of the Adult Interdependent Relationships Act permits partners to enter into an agreement to create an adult interdependent relationship, but also imposes such an arrangement regardless of the parties' wishes in statutorily-prescribed circumstances. ${ }^{30}$ Germany chose the same-sex registered partnerships model. However, unlike Denmark, ${ }^{31}$ Germany did not assimilate the rights granted to registered partners in an across-the-board fashion, subject to limited exceptions, to those available to married persons. Partly, this was a deliberate and free choice of the legislature, ${ }^{32}$ partly, it was inspired by fears of constitutional invalidity, which was believed to be more likely under Art. 6(1) of the Basic Law (the marriage and family provision) the more that those rights and duties associated with same-sex partnership approached those of marriage. The German law is thus a unique solution to the needs of same-sex partners.

Leaving aside fears of constitutional invalidity, which option legislatures choose will depend not only on the compromises inherent in the democratic process and the limitations imposed by public opinion, but also on what precisely it aims to achieve by its law. Speaking rather broadly, there are five possible aims that a legislature may have in mind in this respect. The first two are related to the parties' wishes: ${ }^{33}$ to provide gays and lesbians with a state-

N. Dethloff, "Die eingetragene Lebenspartnerschaft - ein neues familienrechtliches Institut" [2001] Neue Juristische Wochenschrift 2598 at 2598; H.-J. Kanzler, "Erste Überlegungen zur Einkommensbesteuerung der Lebenspartnerschaft nach dem Entwurf des Lebenspartnerschaftsgesetzes" [2000] Finanzrundschau 859 at 859; T. Meyer \& A. Mittelstädt, Das Lebenspartnerschaftsgesetz: Kommentierende Darstellung anhand der Materialien (Cologne: Bundesanzeiger Verlag, 2001) at 22; Schlüter, Heckes \& Stommel, supra note 17 at 3.

Klein, supra note 6 at 434; Meyer \& Mittelstädt, supra note 25 at 23.

Krause, supra note 22 at 212.

For an Australian perspective on other possible options, see Sotirios Sarantakos, "Same-Sex Marriage: Which Way to Go?" (1999) 24 Alt. L.J. 79.

Schlüter, Heckes \& Stommel, supra note 17 at $4 \mathrm{ff}$.

Interdependent Relationships Act, supra note 3.

Art. 3 of the Danish law, referred to supra note 16.

Scherpe, "Zehn Jahre," supra note 16 at 37; Verschraegen, supra note 16 at 71.

For a survey dealing with this question, see H. Weiß \& D. Becker, "Geltendes und Gewünschtes Recht" in Hans P. Buba \& Laszlo A. Vaskovics, Benachteiligungen gleichgeschlechtlich orientierter Personen und Paare (Bundesanzeiger, 4 January 2001, No. 4a) at $104 \mathrm{ff}$. 
sanctioned ceremony at which their union is publicly recognized and affirmed, ${ }^{34}$ or to extend the legal rights, ranging from taxation concessions to the right to refuse to give evidence in court against a partner, that married couples enjoy to homosexuals. ${ }^{35}$ Three broader societal aims may also be pursued: first, to provide protection for partners in a relationship that may be unequal, especially financially ${ }^{36}$ second, to send a message to society that homosexual and heterosexual relationships are of equal worth, and to assist in purging prejudice against homosexuals; ${ }^{37}$ finally, to require partners to contribute to each other's upkeep - thus reducing the burden on the taxpayer if, for example, one partner becomes unable to work. ${ }^{38}$ Each of the possible legislative options will serve these goals to a greater or lesser extent. For example, the "gay marriage" and, depending on the precise form of the ceremony adopted, the two registered partnership models enable an appropriate public ceremony to be held, but they will not necessarily protect the weaker partner in a relationship as the stronger partner can always refuse to opt in. ${ }^{39}$ The two de facto models have the converse effect. The author assesses the German law with respect to these five possible aims once its provisions have been analyzed.

\section{HomoseXuality in the CaSe LAW OF THE German Federal Constitutional Court}

An unabridged history of the legal position of homosexual partners before the enactment of the registered partnerships law cannot be attempted in the space of this article. Nor is this the place for a history of the criminalization of homosexuality in German law - or, rather, the criminalization of male homosexuality, as the practice of lesbianism has never been a

Hans P. Buba \& Laszlo A. Vaskovics, eds., Benachteiligung gleichgeschlechtlich orientierter Personen und Paare (loose-leaf, Bibliothek der Humboldt-Universităt $\mathrm{zu}$ Berlin, Teilbibliothek Kulturwissenschaften, January 2000) at 20; R. Lautmann, "Recht als Symbol: die Gesetzgebung zur gleichgeschlechtlichen Partnerschaft" (2001) 66 Betrift Justiz 100 at 105; MacDougall, supra note 2. Buba \& Vaskovics, ibid. at 19; Eggen, supra note 20 at 445; Krause, supra note 22 at 213, 219.

H. Grziwotz, "Mőglichkeiten der Vertragsgestaltung nach dem LPartG" [2001] Familie, Partnerschaft, Recht 466 at 466 ["Möglichkeiten"]; G. Rieger, "Das Vermögensrecht der eingetragenen Lebenspartnerschaft" [2001] Zeitschrift fur das gesamte Familienrecht 1497 at 1499.

Braun, "Ein neues," supra note 5 at 27 (author opposed to this aim); Buba \& Vaskovics, supra note 34 at 21; Scherpe, "Zehn Jahre," supra note 16 at 36; A. Uhle, "Die "Homosexuellen-Ehe": Diskriminierungsabbau oder Privilegienaufbau?" [2001] Neue Ordnung 84 at 86. It has also been suggested that the recognition of homosexual relationships could be a form of reparation for past persecution. However, this seems to the author to be an unlikely aim for a law that recognizes existing partnerships, which could not exist if there were any substantial form of persecution still in operation, and that enables new partnerships to receive the blessing of the law. Also, such an aim would needlessly distract attention from the practical questions that require attention when framing such a law (Schluter, Heckes \& Stommel, supra note 17 at 18), without helping those who suffered under the earlier regime. Stephan Stüber, "Einleitung" in Manfred Bruns \& Rainer Kemper, eds., LPartG - Gesetz zur Beendigung der Diskriminierung gleichgeschlechtlicher Gemeinschaften: Lebenspartnerschaften Handkommentar (Baden: Nomos, 2001) at xxxix [ Stuber, "Einleitung"] [Bruns \& Kemper]

Bailey-Harris, supra note 23 at 619. 
crime in Germany. ${ }^{40}$ Nevertheless, a brief consideration of the status of homosexuality in German case law is of interest and relevance.

Homosexuality first emerged before the German Federal Constitutional Court in 1957 in a fascinating decision ${ }^{41}$ that reproduces at great length the opinions of various expert witnesses on the nature of both male and female homosexuality. In issue was the validity of ss. 175 and 175a of the Criminal Code, which had been inserted by the Hitler regime in $1935 .{ }^{42}$ Prior to 1935 , s. 175 of the Criminal Code outlawing indecency between men was interpreted to prohibit only acts in the nature of sexual intercourse occurring between men. ${ }^{43}$ The amendments of 1935 were designed to include all forms of indecency between men, ${ }^{44}$ including, for example, mutual masturbation. ${ }^{45}$ Section $175 \mathrm{a}$ was inserted to inflict greater punishments for aggravated forms of homosexual activity between men, such as prostitution, rape, and intercourse with minors. It had already been settled soon after the end of World War II that Nazi laws were not for that reason alone invalid; nor, the Court held, were ss. 175 and 175 a so obviously the product of Nazi ideas that they were incompatible with the new democratic order. ${ }^{46}$ Further, the Court brushed aside the obvious discrimination against men in criminalizing only those homosexual acts committed by men on the ground that the different sexual construction and behaviour of male homosexuals warranted a different legal regime ${ }^{47}$ The Court also rejected the complaint that the prohibition of male homosexuality infringed the basic right to the "free development of the personality" (Art. 2(1) of the Basic Law) on the ground that "homosexual behaviour clearly infringes the moral code" ${ }^{\text {"48 }}$ and thus fell within one of the exceptions to Art. 2(1).

K. Strick, "Gleichgeschlechtliche Partnerschaft - Vom Straftatbestand zum Status?" [2000] Deutsches und europaisches Familienrecht 82 at 82, n. 2. It was otherwise in Austria: see the recent decision of the Constitutional Court in [2002] Juristische Blatter 579 for a summary of the history. It is also hard to resist referring to the Prussian Code of 1794 that criminalized "sodomy, and other similar unnatural sins, which cannot even be named here because they are revolting" (Allgemeines Preußisches Landrecht, s. 1069 II 20, quoted in (1957) 6 BVerfGE 389 at 391).

(1957) 6 BVerfGE 389. The decision is available in English translation, together with a useful commentary, in R. Moeller, "Sex, Society and the Law in the Post-War West Germany: Homosexuality and the Federal Constitutional Court" (Working Paper No. 3.8 of the Centre for German and European Studies, University of California at Berkeley, June 1993). The current author worked from the German original.

42 Reichsgesetzblatt, 5.7.1935, Part I at 841 .

43 This was based on the use of the word "between" in s. 175: (1890) 20 RGSt 225.

44 The Nazis deliberately refrained from punishing lesbians. Their reasons for doing so are set out in Wenzeslaus Graf von Gleispach in F. Gürtner, ed., Das kommende deustche Strafrecht: Besonderer Teil, 2d ed. (Berlin: Fritz Vahlen, 1936) at 204, and include the greater prevalence of male - as distinct from female - homosexuality and its more noticeable nature, together with the fact that fewer women are present in public life, that women tend to be closer to one another (thus making it difficult to recognize the lesbians and producing a danger of false accusation based on everyday intimacy) and that lesbians do not waste the ability to reproduce.

This change was in fact accomplished by a change in the case law just before the law itself came into force (see (1957) 6 BVerfGE 389 at 396). Ibid. at 416-18.

Ibid. at 422-32. This argument was again adopted by the Court in (1973) 36 BVerfGE 41 at $45 f$. (1957) 6 BVerfGE 389 at 434. See further Johannes Wasmuth, "Verfassungsrechtliche Notwendigkeit der Rehabilitierung Homosexueller wegen strafrechtlicher Verfolgung durch die bundesdeutsche Justiz" in J. Becker et al., eds., Festschrift für Manfred Rehbinder (Munich: C.H. Beck, 2002) at 780, n. 27 ["Justiz"]. 
The above example of the ineffectiveness of basic rights provisions against sufficiently strong and widespread prejudice was not a good start. Indeed, until the repeal of the general prohibition of male homosexual activity in $1969,{ }^{49}$ the law of 1935 continued to be applied and interpreted as its authors intended. ${ }^{50}$ As a result, over 50,000 convictions under the law of 1935 are estimated to have occurred between the end of the War and $1969,{ }^{51}$ and the only punishment prescribed was a term of imprisonment. ${ }^{52}$ Unlike the criminal offence of adultery leading to the breakup of a marriage,$^{53}$ there was no provision liberating the prosecution authorities from their obligation to prosecute homosexuals where no complaint had been made.

An interesting comparison may be made with East Germany. The East German Supreme Court rejected the 1935 version of $s .175$ on the ground that it was a specifically Nazi law, ${ }^{54}$ partly because the Nazis' "men's societies offered more opportunities for the practice of homosexuality among men" and s. 175 offered a "useful way of politically and socially discrediting political opponents, in particular Catholic clerics and breakaway National Socialists." ${ }^{55}$ However, both ss. 175 and 175a continued to be applied, the former in its pre1935 version, with indecency being defined as any sexual action "which infringes the feelings of shame and morality of the working class." ${ }^{56}$ However, by 1987, the East German Supreme Court proclaimed that "homosexual people are not excluded from the socialist community, and their civil rights are guaranteed to them as they are to all others." ${ }^{57}$ In so doing, the Court refused to convict a 31-year-old man who had consensual sexual relations with a seventeenyear-old male on the ground that society is not harmed by the technical breach of the criminal law involved in sexual acts with persons under the age of consent prescribed for homosexuals, but above the lower age of consent prescribed for heterosexuals. ${ }^{58}$ This decision (which it should be said, would not have happened without the blessing of, or at least not over the objections of, the Party) led to a relaxation of the Criminal Code provisions

Bundesgesetzblatt, 30.6.1969, Part I at 653.

Risse, supra note 16 at 27.

Johannes Wasmuth, "Strafrechtliche Verfolgung Homosexueller in BRD und DDR" in B. Jellonnek \& R. Lautmann, eds., Nationalsozialistische Terror gegen Homosexuelle: verdrängt und ungesühnt (Paderborn: Ferdinand Schöningk, 2002) at 175 ["Verfolgung"]; Wasmuth, "Justiz," supra note 48 at 778. A precise figure of 44,231 is available for the period from 1950 to 1965 (Muscheler, supra note 23 at 16 ; Risse, supra note 16 at $27 \mathrm{ff}$ ).

Risse, ibid. at $27 \mathrm{ff}$. However, a fine could be substituted for any term of imprisonment of three months or less (Wasmuth, "Justiz," supra note 48 at 174). The Federal German Parliament has since apologized for the practice of prosecuting homosexuals (Stüber, "Einleitung," supra note 38 at xxxviif; Wasmuth, "Justiz," supra note 48 at $788 \mathrm{ff}$ ) and passed a law cancelling convictions under ss. 175 and $175 \mathrm{a}$ (4), although it is confined to the Nazi period (Bundesgesetzblatt, 26.7.2002, Part I at 2714). This makes no sense: either all convictions were tainted (including those after the Nazi period) or none was. See Wasmuth, "Justiz," supra note 48 at 784.

Criminal Code, s. 172 (also repealed in 1969).

Wasmuth, "Justiz," supra note 48 at 778, n. 9.

OG, [1950] Neue Justiz 215 at 215. The decision of the West German Supreme Court in BGHSt 1, 80, 81 reads like a response to this line of argument by the East German Supreme Court.

OG, [1955] Neue Justiz 451 at 451.

OG, [1987] Neue Justiz 467 at 467.

East German Criminal Code, s. 3 authorized courts to refuse to convict in these circumstances, despite the commission of all elements of an offence and the lack of defences. Section 151 provided the higher age of consent (18) for homosexual intercourse. 
and an equalization of the age of consent for homosexual and heterosexual activity less than a year before the fall of the Wall. ${ }^{59}$

Returning to [West] Germany, matters have not remained where they were in 1957. By 1978, the German Federal Constitutional Court was prepared to hold that a transsexual's rights under Art. 2(1) were breached if the authorities refused to amend the entry relating to gender on the official records, ${ }^{60}$ thus prohibiting marriage with a person of the transsexual's former gender. ${ }^{61}$ It is now generally accepted that in addition to the institution of marriage mentioned in Art. 6(1), the choice of other lifestyles, such as living in a de facto relationship, is protected by - and an expression of the right to - the "free development of the personality" to which Art. 2(1) refers. ${ }^{62}$ To this limited extent, it may be said that a change in the meaning of the constitutional provisions, prompted by developments in broader society, has occurred, such that a broader span of possible relationships is now recognized. ${ }^{63}$

Nevertheless, the German Federal Constitutional Court, in rejecting an attempt by samesex partners to marry in $1993,{ }^{64}$ stated that the special protection offered to marriage by Art. 6 (1) remains restricted to marriage between persons of different sexes. ${ }^{65}$ Unlike the Family Law Code of East Germany restricting marriage to heterosexual unions ${ }^{66}$ however, Art. 6(1) merely refers to "marriage" and does not state what sex the parties must be. It is generally agreed that the mention of marriage in Art. 6(1) does not set in stone the institution of

Gesetzblatt der $D D R, 28.12 .1988$, Part I at 335, 339. Despite all this, it should not be imagined that East Germany was a homosexual's paradise: Wasmuth, "Verfolgung," supra note 51 at $178 \mathrm{ff}$. On the current law of England relating to this, see Goodwin v. United Kingdom [2002] 2 F.L.R. 487 (E.C.H.R.); [2002] ECHR 28957/95.

(1978) 49 BVerfGE 286. For another case involving a transsexual, see (1993) 88 BVerfGE 87. For references to recent case law on the subject, see L. Grenfell, "Making Sex: Law's Narratives of Sex, Gender and Identity" (2003) 23 Leg. St. 66 at 66-91; Margaret Otlowski, "What is the Harm in it Anyway? Re Kevin and the Recognition of Transsexual Marriage" (2002) 16 Austl. J. Fam. L. 146. The most recent case is Bellinger v. Bellinger [2003] 2 All E.R. 593 (H.L.).

(1990) 82 BVerfGE 6 at 16; Bruns, "Art. 6(1)GG," supra note 16 at 8; M. Burgi, "Schutzt das Grundgesetz die Ehe vor der Konkurrenz anderer Lebensgemeinschaften?" [2000] Der Staat 487 at 492; Risse, supra note 16 at 246; Stüber, "Gleichstellung," supra note 5 at 595 (with further references to the case law); Zimmermann, supra note 5 at $657 \mathrm{ff}$.

G. Krings, "Die 'eingetragene Lebenspartnerschaft' fur gleichgeschlechtliche Paare: der Gesetzgeber zwischen Schutzabstandsgebot und Gleichheitssatz" [2000] Zeitschrift fur Rechtspolitik 409 at 412. The attempt by gays and lesbians to marry under existing law was dismissed by all but one of the courts below (and the one judgment to the contrary was set aside on appeal). For a reference in English to the background of this case, see Schimmel \& Heun, supra note 8 at 585, and see (in German) Bruns, "Art. 6(1)GG," supra note 16 at 6; Muscheler, supra note 18 at 20; H.-M. Pawlowski, "Abschied von der 'burgerlichen Ehe'?: Ist der Schutz der Ehe durch den Staat noch zeitgemäß?" [2000] Deutsches und europaisches Familienrecht 19 at 20; Risse, supra note 16 at $191 \mathrm{ff}$; Sachs, supra note 5 at 45 ; Schluter, Heckes \& Stommel, supra note 17 at 1; Stuber, "Einleitung," supra note 38 at xxvi; von Munch, infra note 71 at 261; Trimbach, supra note 5 at 399. For a similar case from New Zealand, see Quilter $v$. Attorney-General (New Zealand), [1998] 1 N.Z.L.R. 523 (N.Z.C.A.) [Quilter] and, for an amusing commentary, see J. Allan, "Oh That I Were Made Judge in the Land" (2002) 30 F.L.R. 561 at 569ff. Cases from the United States are cited in Miller, supra note 22. paternalistic, list of what parties to a marriage should consider before embarking on it. 
marriage as it existed when the Basic Law was drafted ${ }^{67}$ However, as the Court confirmed in its decision on the Registered Partnerships Act, ${ }^{68}$ there are core aspects of the institution $^{69}$ - such as its restriction to partners of the opposite sex and to two partners only $^{70}$ - that are not subject to change except by constitutional amendment. ${ }^{71}$ As it is impossible to say what the future will bring, it is sometimes speculated that these apparently unalterable characteristics of marriage may come to be seen as dispensable, and thus subject to change by the legislature. ${ }^{72}$ The Dutch and Belgian laws opening marriage to same-sex partners may be the first step along this road. ${ }^{73}$ The solemnization of "gay marriages" in Canada will also help the cause. However, there is little indication of the sort of overwhelming consensus that would be necessary to justify such a change at the moment. The author, in line with the vast majority of German scholars, ${ }^{74}$ considers it axiomatic ${ }^{75}$ that in referring Art. 6(1) to marriage, relies on a traditional concept involving the union of one man and one woman. ${ }^{76}$

As later discussed, Art. 6(1) fulfills a number of functions. If one of those functions is to guarantee the existence of a legal institution called marriage in some recognizable form, there must be some very basic elements of that institution that cannot be changed by the legislature. Therefore, at least at the present time and probably until an amendment is made, "marriage" in Art. 6(1) does not include marriage between persons of the same sex. This point was confirmed by the German Federal Constitutional Court in upholding the registered partnerships law. ${ }^{77}$ The question of whether a sub-constitutional provision for the marriage of homosexual individuals could be made by the legislature - in other words, whether it could create a form of marriage by statute that would not enjoy the protection of Art. $6(1)-$ has not yet come before the Court. ${ }^{78}$

"The Judgment," supra note 8 at 2547 (with references to earlier cases); Klein, supra note 6 at 435 ; S. Ott, "Der Begriff 'Ehe und Familie' in Art. 6 (1) GG" [1998] Neue Juristische Wochenschrift 117 at 117; G. Robbers, "Eingetragene Lebenspartnerschaften" [2001] Juristenzeitung 779 at 781. "The Judgment," ibid. at 2548. Strick, supra note 40 at 84. (1980) 53 BVerfGE 224 at 245; BVerfG, [1993] Neue Juristische Wochenschrift 3058 at 3058 (with further references to case law); Sachs, supra note 5 at 45.

7 Burgi, supra note 62 at 495 ; I. von Munch, "Antidiskriminierungsgesetz - notwendig oder uberflussig?" [1999] Neue Juristische Wochenschrift 260 at 261. Michalowski \& Woods, German Constitutional Law: The Protection of Civil Liberties (Dartmouth: Ashgate, 1999) at 246-249; Strick, supra note 40 at 83.

Quaere whether recognition of such marriages by German law must still be denied on ordre public grounds (as was once clearly the case) (Kiel in Bruns \& Kemper, supra note 38 at 480 ).

74 C. Freytag, "Lebenspartnerschaftsgesetz, Eheschutzgebot und Differenzierungsverbot" [2002] Die offentliche Verwaltung 445 at 450 ; Klein, supra note 6 at 435 . A total of four dissentients are listed in Krings, supra note 63 at 410, n. 7. See also Risse, supra note 16 at 196-98; Schimmel \& Heun, supra note 8 at 585ff; H. Trimbach, "Ist die Homo-Ehe noch verfassungswidrig?" [1998] Neue Justiz 63 at 66.

75 The axiomatic nature of this proposition was well expressed in Quilter, supra note 64 at $541 \mathrm{ff}$.

76 Braun, "Ein neues," supra note 5 at $25 \mathrm{ff}$; Krings, supra note 63 at 410 ; Robbers, supra note 67 at 781 ; Strick, supra note 40 at 89 ; Uhle, supra note 37 at $88 \mathrm{ff}$; Zimmermann, supra note 5 at $649-53$. In Australia, McHugh J. appears to be of the view that the question is, or shortly may become, an open one: Ex parte McNally: Re Wakim (1999), 198 C.L.R. 511 at 553 (H.C.A.) [McNally].

78 On this question see Bruns, "Art. 6(1)GG," supra note 16 at 10; Ott, supra note 67 at 117; Schluter, Heckes \& Stommel, supra note 17 at 9; Strick, supra note 40 at 86, 90; Stüber, "Einleitung," supra note 38 at xxvii; Stüber, "Gleichstellung," supra note 5 at 596. 
The 1993 decision of the German Federal Constitutional Court rejecting an attempt by same-sex partners to marry merely decided that the Registry Office was not required by existing law nor equality provisions to register a marriage between two persons of the same sex. While rejecting this claim, the Court stated that the legislature "may" restrict marriage to unions "to which the constitutional protection relates"; ${ }^{79}$ although the outcome certainly does not rule out the possibility of some sort of "sub-constitutional" marriage, it is possible to place too much weight on this obiter dictum. More important to the present discussion is the Court's decision to leave open the question of "whether the legislature is required to offer a means of legally securing same-sex relationships or whether, at least, individual rules of law may require amendment in various areas" ${ }^{\prime 80}$ so as to remove discrimination. ${ }^{81}$ Although this was a "panel" decision of the Court denying leave to appeal and not a decision of the full Court binding subsequent Courts, it was a broad hint to the legislature - one that the registered partnerships law has now taken up.

\section{THE LAW}

\section{A. INTRODUCTION}

The German registered partnerships law is dated 16 February $2001^{82}$ and is divided into five "articles," the longer of which are subdivided into individual paragraphs. The division may be compared with that of longer English-language statutes containing parts and sections. The law as a whole is headed An Act to End Discrimination against Same-Sex Relationships: Life Partnerships. Article 1, which contains the rules relating to the new institution of samesex registered partnership, is itself given a heading: "An Act Relating to the Registered Life Partnership (Life Partnership Law)." ${ }^{83}$ All of this makes the law and its component parts unusually difficult to cite. ${ }^{84}$ In this article, no attempt is made to follow this confusing practice. Rather, the whole law is referred to simply as the Registered Partnerships Act or simply, the Act. Section numbers should be taken as referring to Art. 1 of the law, unless the contrary is stated. In quotations taken from the Registered Partnerships Act, the institution creating the $A c t$ is referred to as "the registered partnership" rather than "(registered) life partnership." ${ }^{85}$

BVerfG, [1993] Neue Juristische Wochenschrift 3058 at 3058.

Ibid.

81 See further Bruns, "Art. 6(1)GG," supra note 16 at 10; Freytag, supra note 74 at $452 \mathrm{ff}$; Muscheler, supra note 23 at 35, 40; Sachs, supra note 5 at 45-47; Schluter, Heckes \& Stommel, supra note 17 at 8; Stuber, "Einleitung," supra note 38 at xxvi; Stuber, "Gleichstellung," supra note 5 at 600.

Bundesgesetzblatt, 22.2.2001, Part I at 266. Although it does not affect the following discussion, the law has since been amended in one particular instance by a new law to combat domestic violence (see Bundesgesetzblatt, 17.12.2001, Part I at 3517).

This heading is abbreviated to "LPartG": "G" being the first letter of "Gesetz," which is German for "Act." The equivalent abbreviation for the whole five-article law is the ungainly-looking LPartDisBG; Meyer \& Mittelstădt, supra note 25 at 31.

D. Schwab, "Eingetragene Lebenspartnerschaft: ein Überblick" [2001] Zeitschrift für das gesamte Familienrecht 385 at 387.

The latter being the literal translation of the law's terminology, but which sounds slightly odd in English, possibly because of its ambiguity (is it a partnership for life, or a partnership in life?) and its reminiscence of a "life sentence." 
While one opponent of the law objects to the statement in the law's heading that same-sex partnerships were discriminated against before its enactment, ${ }^{86}$ this fact is not open to serious debate. Such discrimination was constitutionally possible, not only because of the restriction of Art. 6(1) to heterosexual marriage, but also because the Basic Law does not contain an explicit prohibition of discrimination on the basis of sexual orientation. ${ }^{87}$ While same-sex partners who were prepared to incur expense and inconvenience to achieve some of the benefits of marriage could do so by means of private-law arrangements, such as contracts and powers of attorney, ${ }^{88}$ public-law rules could not generally be altered in that manner. ${ }^{89}$ Thus, for example, same-sex partners did not have the same rights as spouses under laws protecting tenancies, ${ }^{90}$ permitting relatives to refuse to testify in court against each other, ${ }^{91}$ or facilitating the grant of permanent residency or citizenship to their non-citizen partners. ${ }^{92}$ Many other examples could be given. ${ }^{93}$ Nevertheless, the lack of public-law recognition of same-sex relationships also may have brought occasional advantages: for example, partners had no legal obligation to provide for each other's financial needs before resorting to public income support. $^{94}$

Like ss. 14-82 of Alberta's Adult Interdependent Relationships Act, Arts. 2 and 3 of the German Registered Partnerships Act remove some - but not all - of the disadvantages suffered by same-sex partners by changing provisions of the Civil Code and other federal laws respectively. Article 3 amends such esoteric laws as the Federal Small Gardens Act, ${ }^{95}$ the Milk and Margarine $A c t^{96}$ and the Driving Instructors $A c t,{ }^{97}$ as well as more well-known

86 Uhle, supra note 37 at $84 \mathrm{ff}, 92 \mathrm{ff}$.

87 Krings, supra note 63 at 410 . However, a few state constitutions do contain such a provision: for references, see Schluter, Heckes \& Stommel, supra note 17 at 6. (2001) 104 BVerfGE 51 at 62f; Schimmel \& Heun, supra note 8 at 76.

Dethloff, supra note 25 at 2604; D. Epple, "Lebenspartnerschaft gleichgeschlechtlicher Paare: Stand der gesetzlichen Regelungen und rechtsgeschăftliche Regelungen" [2001] Zeitschrift für das Notariat in Baden-Württemberg 44 at 44; Trimbach, supra note 74 at 64.

In (1993) 121 BGHZ 116 the German Federal Supreme Court extended rules protecting spouses to heterosexual de facto couples (upheld in (1990) 82 BVerfGE 6 by the Federal Constitutional Court), but expressly excluded homosexual couples (at 124). See further M. Löhnig, "Verănderungen im Recht der Wohnraummiete durch das Lebenspartnerschaftsgesetz" [2001] Zeitschrift für das gesamte Familienrecht 891 at 891 ; Risse, supra note 16 at 35ff; Schlüter, Heckes \& Stommel, supra note 17 at 13. On English law, see infra note 299.

"Risse, ibid, at 34.

92 However, (1996) 100 BVerwGE 287; BVerwG, [2001] Inf. Ausl. R. 72 did concede some limited form of consideration under this heading. See further Risse, ibid. at $34 \mathrm{ff}$; Dirk Siegfried in Bruns \& Kemper, supra note 38 at 318-24; Stuber, "Einleitung," supra note 38 at xxxff.

93. See Bundesrat, Drucksache 544/98, Anlage at 1-3; BVerfG, [1999] Neue Zeitschrift fur Arbeitsrecht 878; BGH, [2002] Zeitschrift für das gesamte Familienrecht 810 at 812; BVerwG, [2000] Neue Juristische Wochenschrift 2038; Risse, supra note 16 at 34-36; Trimbach, supra note 74 at $63 \mathrm{ff}$.

Risse, supra note 16 at 36 . See also (1992) 87 BVerfGE 234 at 267 . This situation has not been entirely reversed by the Court's interpretation of the Registered Partnerships Act, supra note 8 at 2548; Gerd Brudermuller in P. Bassinger et al., eds., Palandt, 61st ed. (Munich: C.H. Beck, 2002) at 2741; Muscheler, supra note 23 at 45,47 . See infra note 290. Art. 3, s. 10. See also Siegfried, supra note 92 at $316 \mathrm{ff}$.

Art. 3, s. 39 .

Art. 3, s. 57; cf. (2001) 104 BVerfGE 51, 62. However, equivalent amendments to the Chimney Sweeps Act were a casualty of the division of the Bill into two parts. See generally Stuber, "Einleitung," supra note 38 at xliv. On whether this is a constitutionally-impermissible discrimination against chimney sweeps, see Manfred Bruns in Bruns \& Kemper, supra note 38 at 153 [Bruns]. 
enactments, such as the Criminal Code ${ }^{98}$ the Code of Civil Procedure ${ }^{99}$ and the Code of Criminal Procedure which now grants registered partners the right to refuse to testify against each other. ${ }^{100}$ There are also one or two other amendments to federal law that are not directly connected with registered same-sex partners, ${ }^{101}$ such as granting stepparents some legal rights in their stepchildren's upbringing ${ }^{102}$ (doubtless inserted because similar rights were extended to registered partners). ${ }^{103}$ Article 4 is a technical provision permitting regulations amended by the $A c t$ to be amended by regulation again in the future. ${ }^{104}$ Article 5 stipulates that the $A c t$ is to come into force on the first day of the sixth month after the Act's publication; accordingly, it came into force on 1 August 2001.

\section{B. ThE First Challenge}

The Act first had to survive an application - brought by the States of Bavaria and Saxony - for what in the English-speaking world would be called an interlocutory injunction. The application was intended to prohibit the Act from coming into force, pending the final determination of the coming constitutional challenge.

The Court rejected the application by five votes to three on $18 \mathrm{July} 2001,{ }^{105}$ less than two weeks before the law was due to come into force. Applying the usual test for an interlocutory injunction, the Court held that an injunction suspending the operation of a law should be granted only if the disadvantage attached to its being found unconstitutional after it had been in operation for some time "clearly outweigh[ed]"106 the disadvantage attached to suspension, as may be suffered by those who would otherwise benefit from the law's operation. The Court ruled that this was not the case here; ${ }^{107}$ the dissenting minority of three held to the contrary. ${ }^{108}$ The majority - citing possible disadvantages to same-sex partners who, by suspension of the law, may be compelled to testify in court against one another or, being foreigners, to leave Germany in the absence of the necessary permission to stay - stated that such disadvantages "are all the more serious given that the legislature has for the first time given rights to people which assist them in the free development of their personalities [as guaranteed by Art. 2(1)] and lead to the removal of forms of discrimination which have lasted

99

100

|01

Art. 3, s. 32 .

Art. 3, s. 16.

Art. 3, s. 18. See Bruns, supra note 97 at 141-43. The same right also exists in civil cases under the newly amended s. 383(1), No. 2a of the Code of Civil Procedure. See further Bruns, ibid. at 144.

The extraneous amendments are listed in Meyer \& Mittelstådt, supra note 25 at 27.

Art. 2, item 13.

D. Kaiser, "Das Lebenspartnerschaftsgesetz" [2001] Juristenzeitung 617 at 624; Schwab, supra note 84 at 386; A. Schwonberg, "Eingetragene Lebenspartnerschaften" [2002] Zeitschrift fur das Fürsorgewesen 49 at 52 ["Eingetragene"].

For a recent analysis of these provisions, see C. Kulpmann, "Änderungen von Rechtsverordnungen durch den Gesetzgeber" [2002] Neue Juristische Wochenschrift 3436.

(2001) 104 BVerfGE 51. See further L.M. Peschel-Gutzeit, "Eindrücke aus der mündlichen Verhandlung vor dem Bundesverfassungsgericht am 11. Juli 2001 zum Lebenspartnerschaftsgesetz" [2001] Familie, Partnerschaft, Recht 431; Schimmel \& Heun, supra note 8 at 590, n. 6; F. Schindler, "Die Entscheidung des Bundesverfassungsgerichts im einstweiligen Anordnungsverfahren zum Lebenspartnerschaftsgesetz" [2001] Zeitschrift fur offentliches Recht in Norddeutschland 424.

(2001) 104 BVerfGE 51 at 55.

Ibid. at 56-60.

Ibid. at 61-63. 
a long time." 109 Some commentators, writing before the judgment of July 2002 upholding the law, saw this statement as a hint about the likely outcome of the case itself. ${ }^{110}$ As it turned out, they were right. Regardless, after the interlocutory decision had been handed down, the way was clear for the first registered partnership to be entered into, as was done amid considerable media interest on 1 August 2001. ${ }^{11}$

\section{Some Political BaCkground}

As we have seen in a panel decision as long ago as 1993, the German Federal Constitutional Court suggested that some form of legal facility may be provided to same-sex partners. However, the matter had a poor chance of being seriously considered by the federal $^{112}$ legislature until the Social Democrats and the Greens formed a coalition after the general elections of mid-1998. ${ }^{113}$ Some manner of same-sex partnership law was promised during the election campaign by the Social Democrats' leader (now Chancellor), Gerhard Schröder. ${ }^{114}$ When the coalition with the Greens was formed after the elections, the coalition agreement contained a clause proposing a registered partnership law. ${ }^{115}$

After some rather difficult negotiations among the two governing parties and the bureaucracy, a bill was introduced to Parliament (Bundestag) on 5 July 2000, and accepted by it on 10 November $2000 .{ }^{116}$ Despite being a joint initiative of the governing parties, it is probably true to say that the project was primarily advanced by the smaller coalition partner, the Greens, ${ }^{117}$ and, in particular, by Volker Beck, an openly-gay Green Member of Parliament. ${ }^{118}$

$110-$ Lid. at 60.

R. Battes, "Probleme bei der Anwendung des Gesetzes uber eingetragene Lebenspartnerschaften" [2002] Familie und Recht 49 at 49; Braun, "Familie," supra note 4 at 105, n. 251 (referring to press reports; Prof. Braun's own view was different, see "Ein neues," supra note 5 at 24); Stüber, "Einleitung," supra note 38 at xxix.

i11 Schindler, supra note 105 at 424.

112 Note, however, the institution of the "Hamburg marriage" created in advance of the Registered Partnerships Act in the State of Hamburg by a law of 14 April 1999. A purely symbolic act, it neither conferred rights nor duties on the partners. Clearly such a law could only satisfy a need a couple might have for a public ceremony and not any other possible aims (except perhaps some slight reduction in prejudice). See further Burgi, supra note 62 at 506; Epple, supra note 89 at 44; von Munch, supra note 71 at 261; Peschel-Gutzeit, supra note 105 at 432; Schimmel \& Heun, supra note 8 at 588; Schluter, Heckes \& Stommel, supra note 17 at 18; Gerhard Stuber, Die eingetragene Lebenspartnerschaft: ein Leitfaden für Behörden (Stuttgart: Richard Boorberg, 2002) at 10; Verschraegen, supra note 20 at 67. For similar initiatives in other parts of the world see also Bailey-Harris, supra note 23 at 619, n. 86; Christensen, supra note 16 at 1734; I. Steinmeister, “'Eingetragene gleichgeschlechtliche Lebensgemeinschaft' - eine Hülle ohne Rechte" [1996] Zeitschrift für Rechtspolitik 214.

On the position of the Christian Democrats, who governed in coalition from 1982 until that point and are currently the chief opposition party, see Burgi, ibid. at 488, n. 8; Strick, supra note 40 at 82, n. 6.

Stuber, supra note 112 at 10; Stüber, "Einleitung," supra note 38 at xxvi.

Reprinted in [1998] Zeitschrift für Rechtspolitik 485 at 499.

For further details, see Stuber, "Einleitung," supra note 38 at xxviii.

Finger, supra note 5 at 204; Schwonberg, "Eingetragene," supra note 103 at 49.

Braun, "Ein neues," supra note 5 at 29. It was also Herr Beck who took on the task of defending the Registered Partnerships Act in Germany's leading legal periodical: see "Die verfassungsrechtliche Begründung der eingetragenen Lebenspartnerschaft" [2001] Neue Juristische Wochenschrift 1894. 
By the time the bill was debated in the Bundestag, the federal government had lost its majority in the Bundesrat (the assembly of delegations selected by state governments in rough proportion to each state's size and which performs the functions of an Upper House). ${ }^{119}$ However, under the Basic Law, ${ }^{120}$ the Bundesrat can veto only certain categories of bills, as specified in various provisions scattered throughout the Basic Law. The general principle is that the Bundesrat can veto any law that would directly affect the interest of the states. With respect to other bills, any objection the Bundesrat raises can be overridden by the Bundestag. However, if any part of a bill contains a provision that renders it liable to the Bundesrat's veto, the case law subjects the whole bill to the veto. ${ }^{121}$ Under these circumstances, the decision was made to divide the original registered partnerships bill into two separate bills that may be called the Registered Partnerships Bill and the Registered Partnerships (Supplementary) Bill. ${ }^{122}$ The former, which was enacted as the Registered Partnerships Act, contained all the provisions that the Bundesrat could not veto. The Supplementary Bill contained all the provisions that the Bundesrat could veto. Speaking generally, it included all provisions regulating state officials' conditions of employment and the procedures that state officials are required to follow in carrying out the Bill's provisions, ${ }^{123}$ together with any provision affecting taxes that, in whole or in part, are required by the Basic Law to be levied for the benefit of the states. ${ }^{124}$ Although dividing bills in this fashion is a relatively common procedure, this was one of the concerns raised in the challenge to the Registered Partnerships Act before the German Federal Constitutional Court.

In due course, the Bundesrat vetoed the Supplementary Bill. ${ }^{125}$ On the other hand, it both confirmed that the Registered Partnerships Bill was not subject to its veto and failed to engage the constitutional mechanism designed for raising objections to bills that it cannot veto. ${ }^{126}$ The latter decision resulted from the abstention of certain states' delegations, owing to the fact that they enjoyed coalition governments consisting of the Social Democrats and the Christian Democrats (the main opposition party). ${ }^{127}$ Therefore, the Registered Partnerships Act was able to become law. The Supplementary Bill remains unenacted,

119 For a detailed explanation of the workings of the Bundesrat in English, see Werner J. Patzelt, "The Very Federal House: the German Bundesrat" in Samuel C. Patterson \& Anthony Mughan, eds., Senates: Bicameralism in the Contemporary World (Columbus: Ohio State University Press, 1999) 59. Art. 77.

It is interesting to note that this previously-settled case law may be called into doubt in the German Federal Constitutional Court's decision on the Registered Partnerships Act (see "The Judgment," supra note 8 at 2546, where the Court lists the case law to date). See also Johannes Masing in H. Mangoldt \& C. Starck, eds., Das Bonner Grundgesetz: Kommentar, 4th ed. (Munich: Franz Vahlen, 2000) at 2679; Stuber, "Einleitung," supra note 38 at xxxiv.

See Bundestag, Drucksache 14/4545. The Bill is also reprinted in Bruns \& Kemper, supra note 38 at 509-39. The name given in German to the supplementary bill was the Lebenspartnerschaftsergănzungsgesetz (LPartGErgG), which translates as indicated above [Supplementary Bill].

Art. 83 of the Basic Law lays down a basic principle: unless otherwise provided, federal laws are to be executed by the states.

Stüber, "Einleitung," supra note 38 at xxxiii.

757th Sess., Debates (1 December 2000) at 551.

Ibid.

Trimbach, supra note 5 at 400 . 
however, owing to the failure of the Bundesrat to agree to it and a lack of progress in further negotiations. ${ }^{128}$

The coalition agreement between the Social Democrats and the Greens, concluded after the elections of 22 September 2002, included a promise to "revise and supplement" the Registered Partnerships Act using the Federal Constitutional Court's decision as a base, and mentioned the Supplementary Bill by name. ${ }^{129}$ It is questionable, however, whether the Supplementary Bill will have a particularly high priority given that the Bundesrat, at the time of writing, is still controlled by the opposition and the somewhat more pressing economic problems currently facing Germany. To the extent that legislation requiring the Bundesrat's consent is proposed to resolve these pressing problems, negotiations with the opposition are expected to concentrate on securing the Bundesrat's consent to those bills. On the other hand, the Court's decision of July 2002 upholding the Registered Partnerships Act may have some effect on such resistance. ${ }^{130}$

\section{FORMATION OF A REgistered PARTNERSHIP}

\section{Section 1(1) of the Registered Partnerships Act decrees:}

[t]wo persons of the same sex may form a registered partnership by declaring mutually, in person and in each other's presence that they wish to enter into a partnership for life (registered partners). The declarations cannot be given subject to a condition or time limitation. The declarations are effective if they are made before the responsible authority. A further requirement for the formation of a registered partnership is that the partners have made a declaration relating to their property rights under s. $6(1) .^{131}$

This provision makes it clear that the German legislature opted for the same-sex registered partnerships model: the partnership is limited to two persons who must be of the same sex and who must opt in by making the said declarations. Sections 1(2)(ii) and (iii) exclude from registered partnership persons who are related to each other as full- or half-siblings or who are descendants in the direct family line. ${ }^{132}$ Despite this prohibition based on similar prohibitions in the law of marriage, ${ }^{133} \mathrm{~s}$. 2 stops short of creating an obligation comparable to that of marriage in the realm of conjugal relations. While s. 1353 of the Civil Code states that spouses are "obliged to live in a marital relationship," which "probably even today" 134

Muscheler, supra note 23 at 24; A. Schwonberg, "Bundesverfassungsgericht stärkt Ehe und Lebenspartnerschaft" [2002] Zeitschrift für das Fursorgewesen 227 at 229 ["stärkt Ehe"]; Stuber, supra note 112 at 5 .

The agreement is available online: SPD < www.spd.de/servlet/PB/menu/1023291/index.html>.

Stuber, "Einleitung," supra note 38 at xxviii. What the current state of the law actually means for registered partnerships is considered in the next section.

"The Judgment," supra note 8.

As an aside, there is a slight difficulty of interpretation relating to former adopted children. See Finger, supra note 5 at 199, 200; R. Kemper, "Ehe und eingetragene Lebenspartnerschaft Übereinstimmungen, Ähnlichkeiten und Abweichungen in den Regelungen der beiden für dauerhafte Lebensbeziehungen gedachten Rechtsinstitute" [2001] Familie, Partnerschaft, Recht 449 at 450 ["Rechtsinstitute"].

See Civil Code, s. 1307

Sachs, supra note 5 at 50 . The last case assuming the existence of such an obligation appears to be BGH, [1967] Neue Juristische Wochenschrift 1078 at 1079. See further J. Gernhuber \& D. CoesterWaltjen, Lehrbuch des Familienrechts, 4th ed. (Munich: C.H. Beck, 1994) at 173; A. Wacke in K. 
is to be read to include a sexual relationship ${ }^{135}$ and certainly sets up a presumption that married persons will agree on a joint residence, ${ }^{136} \mathrm{~s} .2$ of the Registered Partnerships Act merely states that the registered partners are "obliged to shape their lives together." 137

Although the legislature clearly expected that registered partners would live together, ${ }^{138}$ it is not required by the above provision, which also leaves out the sexual relationship impliedly imposed on spouses. ${ }^{139}$ As one commentator pointed out, "shaping lives together," as the law requires, is not the same as "shaping a life together."140 Although no one checks to make sure that married persons are living in a sexual relationship and objections to this legally unenforceable ${ }^{141}$ obligation are easy to make, it would not even be a technical breach of the law for two heterosexual men who intend to "shape their lives together" to enter into a registered partnership. ${ }^{142}$ Repercussions could conceivably be avoided if, for example, one partner is a foreigner seeking residency or citizenship through the other partner. ${ }^{143}$ Of course, the association of registered partnership with homosexuality in the public mind might deter some. As the Act does not presuppose a sexual relationship and contains no other indication that the parties are meant to be faithful to each other, it allows what is known in the homosexual community as an "open relationship."144 All that the Act requires is that the partners form a relationship of mutual support and consideration for each other's needs. ${ }^{145}$ Also, unlike the Civil Code, the Registered Partnerships Act makes no provision for an

Rebmann, ed., Münchener Kommentar zum Bürgerlichen Gesetzbuch, 3d ed. (Munich: C.H. Beck, 1993 ) vol. 7 at 177 . On the history of this provision, see H. Hubner \& R. Voppel in J. von Staudinger, ed., Bürgerliches Gesetzbuch, 13th ed. (Berlin: Sellier-de Gruyter, 2000) at 434ff. The same authors provide a list of discussions on the question of whether s. 1353 requires a sexual relationship at $443 \mathrm{ff}$. Klein, supra note 6 at 436. However, this obligation is unenforceable (see s. 1353(2) of the Civil Code and s. 888(3) of the Code of Civil Procedure). Rape in marriage has been punishable in Germany since 5 July 1997 (see the law amending the Criminal Code in Bundesgesetzblatt, 4.7.1997, Part I at 1607). Gernhuber \& Coester-Waltjen, supra note 134 at $175 \mathrm{ff}$; Wacke in Rebmann, supra note 134 at $174 \mathrm{ff}$. Registered Partnerships Act, supra note 82.

Kemper in Bruns \& Kemper, supra note 38 at 20ff [Kemper]; Schwab, supra note 84 at 390.

V. Arendt-Rojahn, "Aufenthaltsstatus im Ausländerrecht nach dem Lebenspartnerschaftsgesetz" [2001] Familie, Partnerschaft, Recht 464 at 465; Dethloff, supra note 25 at 2600; U. Diederichsen, "Homosexuelle - von Gesetzes wegen?" [2000] Neue Juristische Wochenschrift 1841 at 1842; Kaiser, supra note 103 at $618 \mathrm{ff}$; D. Kaiser, "'Entpartnerung' - Aufhebung der eingetragenen Lebenspartnerschaft gleichgeschlechtlicher Partner" [2002] Zeitschrift fur das gesamte Familienrecht 866 at 869; Kemper, "Rechstinstitute," supra note 132 at 454; Robbers, supra note 67 at 784; Sachs, supra note 5 at 50; Schwab, supra note 84 at 390 . See infra note 224.

Schwab, ibid. at 390 . This is a translation that fairly reflects the sense of the original, although it is in order to point out that the difference between "life" and "lives" is not present in that form in the original. The original German is quite neutral on whether "life" is in the plural or not. Literally translated, the Act says "common lifeshaping." The commentator points out that this is not the same as "shaping of a common life." See supra note 135 . 132 at 450 .

See infra note 161. On the rights of non-citizen registered partners under the new dispensation, see Arendt-Rojahn, supra note 139; Muscheler, supra note 23 at $136 \mathrm{ff}$.

H. Büttner, "Unterhaltsrecht der eingetragenen Lebenspartner" [2001] Zeitschrift fur das gesamte Familienrecht 1105 at 1110; H. Grziwotz, "Die Lebenspartnerschaft zweier Personen gleichen Geschlechts" [2001] Deutsche Notarzeitschrift 280 at 290 ["Geschlechts"]. 
engagement and thus does not deal with questions of liability and property in cases where an "engagement" to become a registered partner is broken off. ${ }^{146}$

Section 1(1) of the $A c t$ states that a registered partnership must be entered into before "the responsible authority." Nowhere in the $A c t$ is "responsible authority" defined. This is because the original bill specified that the responsible authority was to be the Registry Office, and, as the Registry Office is a state authority, this provision required the consent of the Bundesrat and had to be removed. ${ }^{147}$ Thus, there is a division between legal principle, as regulated by federal law, and the law in practice, which is regulated by state law. This federal division of labour is expressly declared as the general rule by Art. 83 of the Basic Law. The effect of this intriguing, if unintended, echo of the Canadian distribution of power under ss. 91(26) and 92(12) of the Constitution Act, $1867^{148}$ is that each state determines by state law which authority within its own territory is the "responsible authority" with respect to the Act. All states have now enacted legislation on the issue. ${ }^{149}$ Most have chosen the Registry Office as the responsible authority, but some have not. ${ }^{150}$ Bavaria, for example, passed legislation declaring notaries public to be the responsible authority. ${ }^{151}$ The Minister of Justice of Bavaria, Dr. Manfred Weiß, made no secret of the fact that this choice was made in part to distance the registered partnership from marriage, ${ }^{152}$ and notaries public may be less able to fulfil the ceremonial aim of some would-be registered partners than the Registry Office. Nevertheless, the Bavarian rule may have the positive side effect of ensuring that persons entering registered partnerships will receive greater expert advice about the consequences of registration from a notary public than they would from a Registry Office. This may assist in protecting the more vulnerable partner in a proposed registered partnership and generally ensure that partners understand what they are doing before they register. ${ }^{153}$

Under s. 1(1), parties to a registered partnership are required to make a declaration ${ }^{154}$ relating to their property relationships under s. $6(1)$ - the particular significance of which

146 Griwotz, "Geschlechts," supra note 144 at 284; Muscheler, supra note 23 at 59f; Stüber, "Einleitung," supra note 38 at xlff. Nevertheless, Kemper, ibid. at 1-3 advocates the analogous application of the rules relating to property and broken-off engagements in the case of broken-off agreements to enter into a registered partnership.

147 Bundestag, Drucksache 14/4545 at 4.

148 Supra note 11.

149 The most recent enactment, at the time of writing, was the State of Thuringia's law of 4 September 2002 (Gesetz- und Verordnungsblatt, 12.9.2002 at 301), which makes the town halls and district councils responsible. On the speed with which the states acted to implement the federal legislation, see generally BVerfG, [2001] Neue Juristische Wochenschrift 3323, which is the case referred to in Schimmel \& Heun, supra note 8 at 590, n. 46; Freytag, supra note 74 at 454; M. Weiß, "Geleitwort" [2001] Mitteilungen des bayerischen Notarvereins (Sonderheft) 1.

150) See the tables and references in [2001] Familie, Partnerschaft, Recht 470; Kemper, supra note 138 at 5; Kemper, "Rechtsinstitute," supra note 132 at 452; Stuber, supra note 112 at 118; Stuber, "Einleitung," supra note 38 at lv-lvii; Trimbach, supra note 5 at $400 \mathrm{ff}$; see also supra note 149.

151 See H.-J. Vollrath, "Notare als zustăndige Behörde nach dem Lebenspartnerschaftsgesetz-Freirăume des Landesgesetzgebers im notariellen Berufsrecht" [2001] Mitteilungen des bayerischen Notarvereins (Sonderheft) 2 at 4 for a detailed proof of the thesis that notaries count as authorities.

152 Weiß, supra note 149 at 1 . This option is therefore rejected by the principal gay and lesbian lobby group (Battes, supra note 110 at 51 ; Braun, "Ein neues," supra note 5 at 24, n. 9).

15. Battes, ibid. at 50ff; Dethloff, supra note 25 at 2599; Grziwotz, supra note 36 at 466.

154 Battes, ibid. at 51; Brudermuller, supra note 94 at 2742; Schwab, supra note 84 at $388 \mathrm{ff}$. Presumably, this is done before the responsible authority, although it is not stated in the Act. 
is discussed in the next section. Here, it is worth noting that this is not an obligation imposed on parties to a marriage who may make a prenuptial contract. ${ }^{155}$ The legislature assumed greater variation within homosexual relationships, not only with respect to questions of residence and sexual relations, but also financially. In particular, homosexual relationships were deemed less likely to include one partner whose job it is to stay at home and look after the children, and more likely to include dual-income couples. ${ }^{156}$ Accordingly, each relationship was believed to require an individualized set of rules about property. This is a perceived reality that would not be recognized by merely subsuming same-sex relationships under the law of [heterosexual] marriage.

Unfortunately, the Registered Partnerships Act does not provide any solution for situations where an error or omission causes a partnership to be entered into without an agreement between the parties on property rights, or where an agreement is not declared in the manner prescribed by s. 1(1). ${ }^{157}$ The majority view among commentators is that such a registered partnership would simply be invalid - that is, it would not come into existence at all - at least where neither an agreement nor a declaration about an agreement is made. ${ }^{158}$ The status of the registered partnership in cases where a false declaration is made, such that the parties either made no agreement or agreed on a different rule from that which they ultimately declared, ${ }^{159}$ is even more unclear. The Registered Partnerships Act also contains no provisions comparable to those permitting the validation or nullification of marriages where there is some defect in the conclusion of the marriage, such as where one of the parties was a minor ${ }^{160}$ or the union is a "sham marriage" designed solely to gain permanent residency status for one of the spouses. ${ }^{161}$ Although this omission has been commented on by a number of authors, ${ }^{162}$ it seems reasonable to omit such provisions from a law applying to relationships far fewer in number and thus requiring a less complicated infrastructure, and from which no

N. Mayer, "Das Gesetz zur Beendigung der Diskriminierung gleichgeschlechtlicher Gemeinschaften: Lebenspartnerschaften" [2001] Zeitschrift für Erbrecht und Vermögensnachfolge 169 at 170, inclines towards such a requirement for marriage as well. Dethloff, supra note 25 at 2601.

157 Section 6(3) deals with cases in which an agreement is invalid, but not with cases in which there is no agreement at all (Dethloff, ibid. at 2601; Kaiser, supra note 103 at 620). Battes, supra note 110 at 52 doubts this, however.

Brudermuller, supra note 94 at 2742; Kaiser, ibid. at 868; Rieger, supra note 36 at 1499; Schwab, supra note 84 at $388 \mathrm{ff}$. Dethloff, ibid. at 2601 appears to be contra, as is Kemper, supra note 138 at 10.

They may do this, among other reasons, because s. 6(1) makes it easier to make some sort of agreements than others - further discussed in the next section, and see infra note 196.

Under s. 1(2)(I) of the Registered Partnerships Act, this is an absolute bar to entering into a registered partnership, unlike in the law of marriage where the bar may be removed by court order in certain circumstances (Finger, supra note 5 at 200; Muscheler, supra note 23 at 64; Robbers, supra note 68 at 784).

161 Registered Partnerships Act, s. 1(2)(iv); Battes, supra note 110 at 53; D. Henrich, "Kollisionsrechtliche Fragen der eingetragenen Lebenspartnerschaft" [2002] Zeitschrift für das gesamte Familienrecht 137 at 137; Kemper, "Rechtsinstitute," supra note 132 at 451 . Given that registered partners are not required to live together, it will be harder to identify such cases than it is with marriages (Muscheler, ibid. at 45, 55).

162 Battes, ibid. at 54; Brudermuller, supra note 94 at 2742; Dethloff, supra note 25 at 2600; Grziwotz, "Geschlechts," supra note 144 at 292ff; Kaiser, supra note 139 at 866-68; Kemper, ibid. at 451; Muscheler, ibid. at 76ff; K. Rellermeyer, "Die eingetragene Lebenspartnerschaft: Grundzuge des LPartG und Auswirkungen auf die Tătigkeit des Rechtspflegers" [2001] Rechtspfleger 381 at 382; Stuber, "Einleitung," supra note 38 at xli. 
children can be bastardized by a declaration of invalidity. Even so, given the express requirement of the declaration of property rights and the errors that can be made in this respect, some further thought should have been given to the consequences of mistakes. It is also worth noting that, whether or not the law of marriage is appropriate for all same-sex relationships, it is at least well-known. Further, adapting it for such relationships does not require a great deal of thought or reinventing of the wheel.

The most remarked-upon omission of the Registered Partnerships Act is its failure to stipulate that a person who has entered into a registered partnership may not later marry until the partnership has been dissolved. Nor, incidentally, is the offence of bigamy ${ }^{163}$ extended to people who enter into a registered partnership before a previous marriage is dissolved, or vice versa, to those who enter into a second registered partnership before the first is dissolved. ${ }^{164}$ Is the multi-person variant to be introduced into Germany by the back door as persons first enter into a registered partnership and then marry? Indeed, there has been much speculation about what one writer amusingly calls the prospect of "bi-bigamy." 165 One opponent of the law has pointed out that on a literal reading, both registered partners could subsequently marry, thus producing a group of four. ${ }^{166}$ As the legislature remembered to provide that people who are already married cannot enter into a registered partnership, ${ }^{167}$ the lack of provision for the reverse situation can hardly be an intentional omission in the interests of polygamy. ${ }^{168}$ Rather, the legislature was concerned that prohibiting persons from marrying may infringe the protection granted to the institution of marriage by Art. $6(1)$, which includes a personal freedom to marry that can be restricted only for very good reason. ${ }^{169}$ However, it can hardly be in accordance with the dignity of marriage, as understood in Western countries, to allow it to exist at the same time as a registered partnership. ${ }^{170}$ Despite this assertion, some commentators have in fact come to the conclusion that "bi-bigamy" is possible under the Act. ${ }^{171}$ Another favoured solution is that entry into a marriage ipso facto dissolves a registered partnership ${ }^{172}$ — the solution adopted by French

Criminal Code, s. 172.

Meyer \& Mittelstädt, supra note 25 at 26.

Battes, supra note 110 at 115 .

Braun, "Ein neues," supra note 5 at 27; see also D. Leipold, "Die neue Lebenspartnerschaft aus erbrechtlicher Sicht, insbesondere bei zusătzlicher Eheschließung" [2001] Zeitschrift für Erbrecht und Vermögensnachfolge 218 at 222.

Section 1(2)(I). However, the choice of words here is misleading, as the question is not, as the law states, whether a registered partnership is actually being carried on, but whether it exists in law (Battes, supra note 110 at 53; Finger, supra note 5 at 200; Muscheler, supra note 23 at 65 ).

Especially as this point was raised during Committee hearings on the Bill (Leipold, supra note 166 at 224). However, note Beck, supra note 118 at 1900 claiming (unconvincingly, in the current author's view) that there was no need for legislation at all.

Battes, supra note 110 at 114f; Braun, "Familie," supra note 4 at 92; Sachs, supra note 5 at 48, 50; Trimbach, supra note 5 at 401 .

J. Eue, "Erbrechtliche Zweifelsfragen des Gesetzes zur Beendigung der Diskriminierung gleichgeschlechtlicher Gemeinschaften" [2001] Zeitschrift fur das gesamte Familienrecht 1196 at 1197; Leipold, supra note 166 at 224.

Braun, "Ein neues," supra note 5 at 27; Henrich, supra note 161 at 141 ; Kemper, "Rechtsinstitute," supra note 132 at 450 ; Mayer, supra note 154 at $172 \mathrm{ff}$; Leipold, supra note 166 at 222.

Brudermuller, supra note 94 at 2742; Freytag, supra note 74 at 447; Kaiser, supra note 139 at $868 \mathrm{ff}$; Meyer \& Mittelstadt, supra note 25 at 37; Muscheler, supra note 23 at 139-41; Robbers, supra note 67 at 785; Schwab, supra note 84 at 389. The argument against is made by Leipold, supra note 166 at 224 . Other suggestions were made by Battes, supra note 110 at 115 ; Beck, supra note 118 at 1900; Dethloff, supra note 25 at 2599; Schwonberg, "Eingetragene," supra note 103 at 51; Stüber, "Einleitung," supra 
law. ${ }^{173}$ However, in its decision of July 2002, the German Federal Constitutional Court stated that the latter option would suddenly change the situation of the other registered partner, over which he or she would have no control. At the same time, the Court confirmed that a prohibition against marriage between registered partners would not infringe the marriage guarantee in Art. 6(1). ${ }^{174}$ Therefore, it is hoped that the law will be amended by the legislature as the Court suggested ${ }^{175}$ and as implied by the reference in the coalition agreement of September 2002, thereby revising the Registered Partnerships Act on the basis of the Court's decision ${ }^{176}$ and removing the current uncertainty.

\section{E. RightS AND DUTIES}

No attempt can be made here to describe all the rights, duties, and consequences attached to a registered partnership. They range across the entire legal system, from labour law ${ }^{177}$ to the law relating to the compulsory seizure of goods for non-payment of a judgment debt. ${ }^{178}$ Rather, the focus here is on three matters: the symbolic question of the names of the partners, the very practical question of their property rights inter se and, finally, some principal areas where there is a marked divergence between the law applying to married persons and that applying to registered partners.

\section{NAMES}

The German law of names tends to be rather less flexible than that of most common-law countries. It is generally much more difficult to change one's name on a whim, as can be done - either formally by deed poll, or informally by adopting a new name - in many English-speaking countries. ${ }^{179}$ For married persons, s. 1355(1) of the Civil Code ${ }^{180}$ decrees that they "should" adopt a joint surname, but goes on to provide that spouses may also retain their prior surnames. Alternatively, one spouse may adopt a double-barrelled name consisting of the pre-nuptial name and the name of the other spouse; the latter name becomes the "official" name of the partnership. ${ }^{181}$ Further rules are provided about what happens in the case of divorce.

note 38 at xxxv.

Art. 515-7 no. 3 of Book 1 of the Civil Code; Schluter, Heckes \& Stommel, supra note 17 at 4.

"The Judgment," supra note 8 at 2547. See also Muscheler, supra note 23 at 40; Schwonberg, "stärkt Ehe," supra note 128 at 227.

"The Judgment," ibid. at 2547.

See SPD, supra note 129.

A. Powietzka, "Eingetragene Lebenspartnerschaft und Arbeitsrecht" [2002] Betriebsberater 146.

Klaus Rellermeyer in Bruns \& Kemper, supra note 38 at 455-57; J. Stamm, "Gleichgeschlechtliche Lebenspartnerschaften in der Zwangsvollstreckung: Auswirkung auf den Vollstreckungsalltag" [2002] Insolvenz und Vollstreckung 52.

Section 3 of the German Change of Names Act of 5 January 1938 requires an "important reason" to be shown for a change of name. On the history of this statute, see W. Loos, Namensänderungsgesetz: Kommentar (Frankfurt: Alfred Metzner, 1970) at 13-18. This statute is, of course, another example of a law from the Nazi era that remains valid.

Following its amendment as a result of the case (1991) 84 BVerfGE 9, which decided that the previous rule infringed the principle of equality between men and women.

Kemper, supra note 138 at 25. 
The Registered Partnerships Act is very similar, except that registered partners "may" 182 choose a common name by declaring such a wish to "the responsible authority." In this way, the $A c t$ deliberately fails to reproduce the symbolism of the law relating to married couples, which assumes that a common surname will be the rule rather than the exception. ${ }^{183}$ However, at the same time, registered partners are empowered - if they so desire - to take the symbolic step of adopting a joint name. Given that the law permits a somewhat looser coalition between registered partners - not assuming that, for instance, partners will necessarily live together - this situation is quite logical. Accordingly, if Hans Müller enters into a partnership with Jürgen Schmidt, Hans may call himself Hans Schmidt, Hans Müller, Hans Müller-Schmidt or Hans Schmidt-Müller. In the last two cases, Jürgen's name cannot have changed, and must be the "official" name of the partnership. In the second case, Jürgen may call himself Müller (which becomes the partnership's "official" name) or Schmidt. In the first case, both partners are called Schmidt. It is not permissible for both parties to adopt the name Schmidt-Müller or Müller-Schmidt, however. ${ }^{184}$

If a registered partnership using a joint surname is terminated, s. 3(3) of the Act provides, in the same way as other laws provide for divorced persons, that the parties retain the name they had during the partnership. However, by making a declaration before "the responsible authority," parties may re-assume an earlier name, either solely or in conjunction with the name that they had during the partnership.

\section{PROPERTY}

As previously mentioned, the Registered Partnerships Act mandates that the parties reach an agreement on the property relations between them during the existence of the registered partnership and upon its termination. ${ }^{185}$ This is not required of parties to a marriage, who may make a prenuptial contract but are not compelled to do so. If they do not, the law provides that their property must continue to be held separately during the marriage (except, of course, for anything they acquire jointly in fact). However, on the termination of a marriage by divorce, an increase in the property holdings acquired by both parties during marriage is to be seen as the product of their joint efforts. Accordingly, arrangements must be made for

$182 \quad$ Supra note 82, s. $3(1)$.

183 Brudermuller, supra note 94 at 2743; Kaiser, supra note 103 at 618; Kemper, supra note 138 at $24 \mathrm{ff}$; Kemper, "Rechtsinstitute," supra note 132 at 453; Mayer, supra note 155 at 170; Rellermeyer, supra note 162 at 382; Stuber, supra note 38 at xli; Trimbach, supra note 5 at 401 . Muscheler, supra note 23 at $146 \mathrm{ff}$.

185 Termination is inevitable, given that both partners will eventually die. The property arrangements between registered partners do have an influence on the distribution of property after death, but, as this is a complicated area, no further attempt will be made to deal with it here. See s. 6(2) of the Registered Partnerships Act, picking up s. 1371 of the Civil Code, and, e.g., Brudermuller, supra note 94 at 2747. The rules relating to inheritance by registered partners (s. 10 of the $A c t$ ) are very similar to those applied to married persons (Kemper, supra note 138 at 89; Kemper, "Rechtsinstitute," supra note 132 at 457 ; Leipold, supra note 166 at 222). However, insoluble problems are caused if "bi-bigamy" is permissible (Battes, supra note 110 at 115; Eue, supra note 170; Leipold, ibid. at 222f; Mayer, supra note 155 at 173). 
transferring property to the spouse who would otherwise be left with less than a fair share of the jointly-produced property. ${ }^{186}$

Section 6 of the Registered Partnerships Act provides that the parties to a registered partnership may agree on the form of property holding outlined above. ${ }^{187}$ If they do so, they need only agree on this solution and declare that fact to "the responsible authority" when entering into the partnership. Should they wish to conclude any other form of agreement, they must do so by a written contract that requires the certification of a notary public. ${ }^{188}$ There are a number of problems with this rule. First, the $A c t$ does not state what other forms of property holding may be agreed upon ${ }^{189}$ and while it may be assumed that the general principles relating to freedom of contract apply on the one hand, and those relating to unconscionable contracts and contracts against public policy apply on the other ${ }^{190}$ there is debate about whether the Act permits the partners to agree to own all property jointly, as married couples can. ${ }^{191}$ This is a question that might have been dealt with expressly in the $A c t$ itself, but which now must be resolved by case law. ${ }^{192}$

The provisions of the Act with respect to property have been cogently criticized for other reasons. First, s. 6(3) provides that where an agreement between the parties is invalid, such as through misrepresentation or lack of contractual capacity, ${ }^{193}$ they hold their property separately, and no adjustment of increased assets is to take place after the end of the partnership. The reason for this rule is very unclear. The most that can be said for it is that it preserves the status quo before the partnership was entered into. ${ }^{194}$ However, it not only deviates from the rule that the division of property most easily arranged - and thus, presumably preferred ${ }^{195}$ - is separate ownership with an adjustment on termination; ${ }^{196}$ it also appears to offer little protection to a weaker party in precisely the situation where such

186 Although the rules are more complicated than this, the present summary is broadly accurate. See further, e.g. D. Schwab, Familienrecht, 10th ed. (Munich: C.H. Beck, 1999) c. 5. Kemper, ibid. at 42-65 deals with this area in the context of registered partnerships.

It is called by a different name (Ausgleichsgemeinschaft) from that used for the equivalent institution in marriage (Zugewinngemeinschaft), but the two are the same in all other respects (Brudermuller, supra note 94 at 2744; Kemper, "Rechtsinstitute," supra note 132 at 456; Rellermeyer, supra note 162 at 382; Rieger, supra note 36 at 1502; Schwab, supra note 84 at 388; Trimbach, supra note 5 at 401 ).

Registered Partnerships Act, supra note 82, s. 7(1).

Leipold, supra note 166 at 220; Rieger, supra note 36 at 1506.

Schwonberg, "Eingetragene," supra note 103 at 55.

Brudermuller, supra note 94 at 2745; Dethloff, supra note 25 at 2601; H.-J. von Dickhuth-Harrach, "Erbrecht und Erbrechtsgestaltung eingetragener Lebenspartner" [2001] Zeitschrift fur das gesamte Familienrecht 1660 at 1663; Epple, supra note 89 at 46; Grziwotz, "Geschlechts," supra note 144 at 287; Kemper, supra note 138 at 36, 69; Rellermeyer, supra note 162 at 382; Rieger, supra note 36 at 1501; Schwab, supra note 84 at 388; Holger Stadie in Bruns \& Kemper, supra note 38 at 554.

For references to other possible arrangements that may be made in the contract (e.g., relating to the division of labour between the parties, living allowances to be paid by one to the other, and even sexual arrangements), see Epple, ibid. at 46; Grziwotz, ibid. at 285; Rellermeyer, ibid. at 382; Rieger, ibid. at 1506.

For example, due to misrepresentation or lack of contractual capacity (Kaiser, supra note 103 at 620). Rieger, supra note 36 at 1498. See also Muscheler, supra note 23 at 74 and Rieger, ibid. at 1501. Leipold, supra note 166 at 219.

Therefore, it has been discussed whether parties who wish to have separate ownership with no termination could make a deliberately invalid contract to some other effect, and then rely on s. 6(3) to bring about the result that they prefer (Battes, supra note 110 at 52). 
protection is required. ${ }^{197}$ Secondly, making it easier to opt for the post-termination adjustment solution by requiring all other arrangements to be certified by a notary public is similarly open to convincing objections. Admittedly, it means that the property relationships between registered partners can most easily be assimilated with those generally applicable between spouses. However, if that was desired, it is hard to understand why the legislature did not simply, as with marriage, make this the default option unless the parties agreed otherwise. Given that parties to a registered partnership may be in a somewhat looser union and also less dependent on each other than married persons with children, ${ }^{198}$ it is not at all clear that this should be the general solution applicable to registered partnerships. It is easy to imagine that the prospect of paying a notary public to certify a contract will prompt parties to adopt the post-termination adjustment solution - which can be done by oral contract ${ }^{199}$ - even where it is inappropriate or unnecessary in their situation, as it well may be for dual-income couples without children. ${ }^{200}$ In this respect the Bavarian law requiring parties to attend a notary's office to enter into a registered partnership does seem to be preferable, as at least it means that competent advice about property relationships will be available. ${ }^{201}$ In other states in which a Registry Office official or some other non-legally-trained government employee attends to the ceremony of partnership, it is easy to imagine the parties attending at the relevant office, being told that they can adopt only one solution on the spot without going to a notary, perhaps being advised inadequately, incorrectly, or not at all by the Registry Office about the consequences involved in each possible course, and deciding to take the easiest way out. This may in turn lead to claims against the Registry Office (or other government authority) for providing false or inadequate advice. ${ }^{202}$ However, there appears to be no research into the effect of these rules on the behaviour of persons entering into registered partnerships as yet.

Whichever form of joint or separate property ownership the parties agree upon, the Registered Partnerships Act, by referring in s. 8(2) to ss. 1357 and 1365-1370 of the Civil Code, implies that the doctrine of mutual agency ${ }^{203}$ and rules preventing one party from disposing of all ${ }^{204}$ his or her assets or household items ${ }^{205}$ without the consent of the other apply to the partnership. This goes further than the law of marriage, which implies the latter

197 Brudermüller, supra note 94 at 2744. It has therefore been suggested that parties should include in their contract special provisions in case of the invalidity of the rest of the contract (Grziwotz, "Geschlechts," supra note 144 at 288 ; see also Stüber, "Einleitung," supra note 38 at xlii).

Grziwotz, ibid. at 283.

Brudermüller, supra note 94 at 2744 . Grziwotz, "Möglichkeiten," supra note 36 at 467 points out that the law could also have been clearer on this point.

Battes, supra note 110 at 50; Brudermuller, ibid. at 2744; Kaiser, supra note 103 at 623; G. Langenfeld, "Der Vertrag der eingetragenen Lebenspartnerschaft" [2002] Zeitschrift für Erbrecht und Vermögensnachfolge 8 at 10; Muscheler, supra note 23 at 74; Rieger, supra note 36 at 1500.

Battes, supra note 110 at 50; Grziwotz, "Möglichkeiten," supra note 36 at 466 . All notaries public in Germany are legally trained and defined as holders of a public office (Bundesnotarordnung (Federal Notaries Ordinance) ss. 1, 6 (subject to possible minor exceptions under ss. 114, 115)).

Mayer, supra note 155 at 171 .

Upheld as constitutional by the German Federal Constitutional Court in (1990) 82 BVerfGE 1. For criticism of this concept, see Muscheler, supra note 23 at 93-96.

Which is interpreted to mean almost all (see Kemper, supra note 138 at 68, 77ff; Muscheler, supra note 23 at $97 \mathrm{ff}$ ).

As is pointed out by Kaiser, supra note 103 at 620 , this provision is particularly odd given that there is no provision requiring the registered partners to have a joint household. 
set of rules only where the parties' property is held in separate ownership with an adjustment on termination. The reason why the Act goes further is not clear, ${ }^{206}$ and some commentators suggest that partners should expressly exclude these provisions. ${ }^{207}$

As far as ongoing financial relations between the parties are concerned, s. 5 of the Registered Partnerships Act declares that during the continuance of the partnership, the parties owe each other "appropriate support." What this means will vary from case to case, but, as the concept of "appropriate support" also appears in the law of marriage, ${ }^{208}$ there is some legislation ${ }^{209}$ and case law on which to fall back. ${ }^{210}$

\section{OTHER RIGHTS AND DUTIES: COMPARISON WITH MARRIAGE}

Other notable differences exist between married couples and registered partners. Many of these are the result of the non-enactment of the Supplementary Bill, and may be removed in due course. For example, although registered partners share similar rights of inheritance to married spouses, ${ }^{211}$ they are treated as strangers by the inheritance tax system. ${ }^{212}$ The lack of any special provision in taxation law for registered partners who inherit from each other continues, and the federal civil service laws ${ }^{213}$ also remain unamended and lack express provisions for civil servants' registered partners. ${ }^{214}$

However, one major difference is the result of a deliberate decision by the government, rather than its inability to have proposed legislation passed. Section 9(1) of the Registered Partnerships Act provides that a registered partner's child, for which he or she has sole custody rights, is subject, provided that the partner agrees, ${ }^{215}$ to the non-custodial partner's

Braun, "Familie," supra note 4 at 74; Grziwotz, "Geschlechts," supra note 144 at 291; Leipold, supra note 166 at 220; Meyer \& Mittelstädt, supra note 25 at 27; Muscheler, supra note 23 at 100; Rellermeyer, supra note 162 at 382; Rieger, supra note 36 at 1507 . Henrich, supra note 161 at 139 , suggests that it is simply a drafting error. Dethloff, supra note 25 at $2601 \mathrm{ff}$, suggests that it is a good idea to prevent parties from destroying the material basis of the partnership, but parties who have chosen separate property ownership with no adjustment on termination have surely waived this protection, too. Similar provisions in the law of Denmark were deliberately not included in its registered partnerships law (Ring \& Olsen-Ring, supra note 16 at 461 ). Langenfeld, supra note 200 at 9; Mayer, supra note 155 at 172.

Civil Code, s. 1360. However, in the Registered Partnerships Act there is no equivalent of the Civil Code's provision that appropriate support may be provided by household work (Schwab, supra note 84 at 391 ). This is clearly based on the assumption that few registered partners will stay at home and look after the house and children. But surely some might.

Section 5 expressly picks up ss. $1360 \mathrm{a}$ and $1360 \mathrm{~b}$ of the Civil Code, on which see Kemper, supra note 138 at 30-32.

Buttner, supra note 144 at 1106; Mayer, supra note 155 at 170; Schwab, supra note 84 at 391 ; G. Weinreich, "Das Lebenspartnerschaftsgesetz" [2001] Familie und Recht 481 at 482. Muscheler, supra note 23.

von Dickhuth-Harrach, supra note 191 at 1670; Grziwotz, "Geschlechts," supra note 144 at 300; Kemper, "Rechtsinstitute," supra note 132 at 458; Langenfeld, supra note 200 at 8; Stadie, supra note 191 at 547-55; Stuber, "Einleitung," supra note 38 at xliii. respects to provide benefits to registered partners. 
capacity to share in the making of decisions "in everyday matters." 216 There is no provision for joint adoption ${ }^{217}$ of a child by registered partners. ${ }^{218}$ Although joint adoption by registered partners is possible in a minority ${ }^{219}$ of European countries, ${ }^{220}$ those responsible for the German legislation thought that it might stir up further opposition to the bill and should therefore be omitted. ${ }^{221}$ It is possible that this question may be reconsidered after a few years' experience with registered partnerships. ${ }^{222}$

\section{F. "DIVORCE"}

Owing to space restrictions, this article will not discuss the legal situation of registered partners who have separated but have not yet terminated the partnership. However, it is difficult to avoid remarking on the fact that Division 3 of Art. 1 of the Registered Partnerships Act, which deals with this situation, is headed "Registered Partners Living Separately," a concept that is then used throughout the rest of the division as the test of separation. It is unclear how this wording can be reconciled with the fact that, as we saw above, registered partners are not required to live together in the first place. There will be difficulties of interpretation and proof ${ }^{223}$ when the parties have never lived together at all. "Living separately" is a poor choice of words. ${ }^{224}$

Together with a power (s. 9(2)) to make decisions in emergencies. Everyday matters include things such as writing notes for school, deciding what television programs to watch, when the child is to go to bed and so on (Kemper, supra note 138 at 86; Schwonberg, "Eingetragene," supra note 103 at 52).

Of course, the other registered partner could simply adopt the child alone, but that would mean that the registered partner who is biologically the parent would cease to be so legally (Kaiser, supra note 103 at 624).

Note, however, that some rights extended to employees with children (e.g., sick leave when the child is sick) are also extended to registered partners: (Powietzka, supra note 177 at 147). In addition, there are access rights created by the Registered Partnerships Act (Art. 2, Item 12, amending s. 1685(2) of the Civil Code) for former registered partners if a child cohabited with that person for a substantial period and access serves the well-being of the child. This is the legislature's answer to the decision of the OLG Hamm, [2000] Neue Juristische Wochenschrift 2684 (see Muscheler, supra note 23 at 19193). Kemper, "Rechtsinstitute," supra note 132 at 454.

In Iceland, Denmark, and Holland: Dethloff, supra note 25 at 2604, n. 41 ; Scherpe, "Zehn Jahre," supra note 16 at 32-34; Scherpe, "Erfahrungen," supra note 16 at 440 . Art. 17b(4) of the Introductory Law to the Civil Code prevents the use of partnerships registered in these foreign countries as a back door to adoption of children in German law: Kiel, supra note 73 at 479. Kemper, "Rechtsinstitute," supra note 132 at 454; Schwonberg, "Eingetragene," supra note 103 at 53. As happened in Denmark (supra note 220). In favour of doing so: Dethloff, supra note 25 at 2602; Grziwotz, "Geschlechts," supra note 144 at 283. Against in principle: Schluter, Heckes \& Stommel, supra note 17 at 11 (together, no doubt, with all those who opposed any sort of recognition for same-sex partners). It is said by Buba \& Vaskovics, supra note 34 at 6 and Vaskovics, "Zusammenfassung und Diskussion" in Buba \& Vaskovics, supra note 33 at 246, that few children live with two homosexual partners at present, but the change of the law in Denmark was said to have been prompted by numerous such cases (Scherpe, "Zehn Jahre," supra note 16 at 34; Scherpe, "Erfahrungen," supra note 16 at 440). See further on gay and lesbian people as parents (H. Weiß, "Elternschaft" in Buba \& Vaskovics, supra note 33 at c. 7).

Braun, "Familie," supra note 4 at 82 , concludes from this that partners do in fact have to live together, but there is little support for this view (supra note 139). However, the question is left open by Schwab, supra note 84 at 391 . See also Muscheler, supra note 23 at 131-39. 
Moving on to "divorce," the legislature's choice of words has again been cogently criticized. The word chosen to describe the dissolution of a partnership is Aufhebung - the word used in Germany not for divorce (Scheidung), but for a court's nullification of a marriage based on defects in its formation, such as the incapacity of one party to marry, or a marriage within the prohibited degrees. ${ }^{225}$ As discussed, there is no exact equivalent of nullification in this sense in the law of registered partnerships, as any such defects lead to a "partnership" being void ab initio. Aufhebung, as used in the Registered Partnerships Act, is translated here as "dissolution" to reflect its function in the law of registered partnerships as the equivalent of divorce.

As in the law of marriage, the Registered Partnerships Act assumes that registered partnerships will be entered into for life. ${ }^{226}$ However, s. 15(2) of the Act states that a registered partnership can be dissolved by a court where both parties declare that they wish to dissolve it and 12 months have elapsed; if one partner has so declared and 36 months have elapsed; or, as the law rather awkwardly puts it by following the law of marriage, where for one registered partner the continuation of the partnership would represent "an unreasonable hardship for reasons which are due to the person of the other."227 Examples of such hardships, derived from the law of marriage, include alcoholism, repeated refusal to engage in sexual relations (which may be questionable in registered partnerships where no such obligation exists), violence, prostitution, child abuse, and particularly bad examples of insulting or degrading behaviour. ${ }^{228}$

If one of these three criteria is satisfied, the registered partnership may be dissolved by a court, as is the case with marriage. The periods of one year and three years, depending on whether the parties agree, are also modelled on those applicable to the law of marriage ${ }^{229}$ In contrast, however, the periods for registered partners do not run from the date of separation, but from the date on which the declarations referred to in s. 15(2) are made. ${ }^{230}$ This may reflect the fact that registered partners are not required to live together in the first place and hence will not necessarily separate, ${ }^{231}$ along with the dispensation in the Registered Partnerships Act with the concept that the breakdown of the relationship is the overarching justification for divorce in marriage ${ }^{232}$ - a concept that, incidentally, was first introduced into German law by the Nazis. ${ }^{233}$ The necessary declarations are the only requirement, which at least produces some small benefits in the area of proof. However, this also makes the dissolution of a registered partnership slightly more difficult than divorce, as registered

Civil Code, s. 1314. See Battes, supra note 110 at 113; Brudermuller, supra note 94 at 2749; Finger, supra note 5 at 201; Kaiser, supra note 139 at 866 ; Weinreich, supra note 210 at 486.

See supra note 82, s. 1(1) of the Act which refers to a partnership for life.

Civil Code, s. 1565(2).

Kaiser, supra note 139 at 872 (suggesting a more liberal interpretation of "unreasonable hardship" than in the law of marriage; Kemper, supra note 138 at 179; see also Battes, supra note 110 at $113 \mathrm{ff}$; Dethloff, supra note 25 at 2603); Stuber, supra note 112 at 23.

Civil Code, s. 1565.

Brudermüller, supra note 94 at 2749; Büttner, supra note 144 at 1106; Kaiser, supra note 103 at 621 . Kaiser, supra note 139 at 869, answering the point made in Finger, supra note 5 at 201.

Civil Code, s. 1565(1); Battes, supra note 110 at 113; Dethloff, supra note 25 at 2603; Grziwotz, "Geschlechts," supra note 144 at 293; Kaiser, supra note 139 at $869 \mathrm{ff}$ (with further references); Kemper, "Rechtsinstitute," supra note 132 at 457; supra note 155 at 174; Meyer \& Mittelstadt, supra note 25 at 25; Schwab, supra note 84 at 398.

See (1980) 53 BVerfGE 224 at 228. 
partners will generally not make declarations immediately after the relationship has broken down but will wait until either the need to do so arises or the breakdown is seen as permanent. ${ }^{234}$ Unlike married couples who do not need to do anything beyond separate in fact, registered partners are not able to initiate the waiting period except by taking additional action, which may well be delayed. This difficulty could easily have been overcome by the adoption of shorter waiting periods for registered partners than those applicable to spouses. Although s. 15(3) of the Act does permit partners to withdraw their declarations before the dissolution of the partnership, those partners aware of the need to make a declaration to set time running may make such a declaration prematurely, which, in turn, may worsen their relationship with the other registered partner and hinder a possible reconciliation. Further, if a declaration is, withdrawn, any renewed declaration is subject to the full waiting period, which makes reconciliation attempts conducted by withdrawal of a declaration particularly risky. ${ }^{235}$ Section 10 of Alberta's legislation provides a much better model in these respects. ${ }^{236}$

Two further questions will have to be resolved through the case law, should they arise. First, it must be determined whether a notary public can certify declarations under s. 15(3) that are made at regular intervals merely to ensure that the registered partnership could be swiftly dissolved should the need arise and, if so, whether such declarations are valid. ${ }^{237}$ Second, in the absence of the concept of nullification such as exists in the law of marriage, courts will have to decide whether general principles of civil law, such as misrepresentation or mistake, offer an alternative avenue for disposing of a registered partnership brought about by those means. ${ }^{238}$ This last point in particular should have been dealt with expressly in the legislation.

With respect to maintenance of a former partner after the dissolution of the partnership, s. 16(1) of the Act decrees that parties owe each other "appropriate support, having regard to the standard of living during the partnership, to the extent that and for as long as employment cannot be expected of [the former partner], owing for example to age or illness or other incapacity." ${ }^{239}$ This rule differs in a number of respects from the rule applicable after divorce ${ }^{240} \mathrm{Light}$ is further shed on the concept of registered partnership by the rule in s. 16(1) that all sorts of employment must be accepted by a former partner before resorting to support from the other former partner. Former spouses, by contrast, are permitted to decline

Brudermüller, supra note 94 at 2741, 2479; Dethloff, supra note 25 at 2603; Grziwotz, supra note 144 at 294; Kaiser, supra note 103 at 621 ; Kaiser, supra note 139 at 873.

Finger, supra note 5 at 202; Kaiser, ibid. at 871. Civil Code, s. 1567(2) assists reconciliation in marriage by stating that short periods of living together in an attempt to reconcile do not interrupt the necessary waiting periods for divorce. There is no equivalent in the law of registered partnerships. Interdependent Relationships Act, supra note 3.

Battes, supra note 110 at 114; Brudermuller in Palandt, supra note 94 at 2750; Finger, supra note 5 at 202; Grziwotz, "Geschlechts," supra note 144 at 294; Kaiser, supra note 139 at 870.

Battes, ibid. at 54; Braun, "Familie," supra note 4 at 98 f; Brudermüller, supra note 94 at 2742; Dethloff, supra note 25 at 2600; Grziwotz, ibid. at 292f; Kemper, supra note 138 at 11-18; Muscheler, supra note 23 at 81 ; Schwab, supra note 84 at 388; Stüber, "Einleitung," supra note 38 at xli; Weinreich, supra note 210 at 481.

"The Judgment," supra note 8.

For further differences, see Battes, supra note 110 at 117-19; Brudermuller, supra note 94 at 2750; Kaiser, supra note 103 at 622; Kemper, "Rechtsinstitute," supra note 132 at 455; Schwab, supra note 84 at 392; infra note 290. 
employment that is not "suitable"241 for them, having regard to such things as their qualifications, age, health, and position in life. ${ }^{242}$ Thus, even after the partnership is dissolved, the legislature expects both parties to be economically independent of each other, ${ }^{243}$ and does not assume that one party's ability to find employment may have been lessened by caring for children. Nor, for the same reason, is there any provision in the Registered Partnerships Act, unlike in the law of marriage, for an equalization of superannuation and other similar arrangements. ${ }^{244}$

\section{THE CASE}

\section{A. INTRODUCTION}

As mentioned earlier, the constitutional challenge to the Registered Partnerships Act was rejected by the German Federal Constitutional Court on 17 July 2002. This occurred by the relatively narrow margin of five votes to three. There were two dissenting opinions, which is itself a much less frequent occurrence in Germany than in the English-speaking world. Mr. Justice Papier wrote for himself and another Justice, who is not named in the report. ${ }^{245}$ The dissenting judges would have invalidated the Registered Partnerships Act under Art. 6(1) (the marriage and family provision); Madam Justice Haas added her view that the law was incompatible with Art. 3(1) (the equality provision).

In the lead-up to the case, the law, although not short of defenders, ${ }^{246}$ was vigorously attacked by a number of commentators: one declared it to be "obviously" 247 unconstitutional; another held that it was invalid on the newly-invented ground of "perplexity";,248 and a third asked, in so many words, whether it represented a "first step towards the normalization of paedophilia."249 The vigour with which the law was opposed on supposedly "neutral" constitutional grounds gives rise to the suspicion that some people confused their views about what the Constitution should say and the desirability of the $A c t$, on one hand, with what the law actually provides on the other, allowing themselves to be carried away by their dislike of the law as a matter of legislative policy. At any rate, the hopelessness of some of the

Civil Code, s. 1574(1).

Brudermuller, supra note 94 at 2751; Grziwotz, "Geschlechts," supra note 144 at 296; Kaiser, supra note 103 at 622; Meyer \& Mittelstadd, supra note 25 at 25; Muscheler, supra note 23 at 230. This point appears to be missed by Kemper, supra note 138 at 183.

Battes, supra note 110 at 117.

Braun, "Familie," supra note 4 at 88; Kemper, supra note 138 at 44, 194; Langenfeld, supra note 200 at 9; Mayer, supra note 155 at 175; Meyer \& Mittelstaddt, supra note 25 at 26; Muscheler, supra note 23 at 87; Stuber, "Einleitung," supra note 38 at xliii. But see Brudermüller, supra note 94 at 2748, 2751.

Nor is he named on the Court's official copy of the judgment on its web site. However, the report (including the official report: (2002) 105 BVerfGE 313, 357), states clearly that three judges dissented. It may be inferred that the other justice agreed with Mr. Justice Papier rather than Madam Justice Haas, as the report states that no other justice shared her views on the challenge under Art. 3. It may be assumed that the third dissenter was Mr. Justice Steiner, who also dissented on the application for an interlocutory injunction.

Even in the most unexpected and indeed inappropriate places (G. Bertram, "Progressiver Probelauf bei Schönfelder" [2001] Neue Juristische Wochenschrift 342).

Uhle, supra note 37 at 93.

Leipold, supra note 166 at 224.

Braun, "Ein neues," supra note 5 at 28. 
arguments against the law indicates that emotion may have overtaken reason in some respects. The following consideration of the case commences with the most hopeless argument of them all.

\section{B. Dividing the BILlS to AVOId the BUNDESRAT}

The Court began its consideration of the law by holding that the Registered Partnerships $A c t$, in the form in which it had been enacted, did not require the consent of the Bundesrat. Although a few of the amendments made to federal laws by Art. 3 affected state agencies, this was, generally speaking, merely a case of expanding their already existing powers to include registered partners as well as spouses. ${ }^{250}$ Also, the Court confirmed ${ }^{251}$ that the federal legislature had the power to enact the legislation under Art. 74(1)(ii) of the Basic Law, which confers concurrent power on the federal legislature to legislate on the status of persons. ${ }^{252}$ Thus, the question that often arises in federal countries - that is, which level of government has the power to enact legislation ${ }^{253}$ — does not arise in this area of German law.

However, the objection raised under this heading was not entirely unconnected with federalism, for, as we have seen, the internal workings of the federal legislative process reflect a concern to uphold federalism. The objection raised was that the federal Lower House (the Bundestag) was not entitled to divide the proposed law into two bills, with one bill not requiring the Bundesrat's approval, to get around the constitutional obstacle that legislation affecting the states' interests (including their administrative apparatus) requires the approval of the Bundesrat. ${ }^{254}$ This objection had no chance of success for two reasons. First, the Court's case law has long recognized the legitimacy of dividing bills, as was done here. $^{255}$ The only restriction that has been suggested ${ }^{256}$ is that the divisions must not be "arbitrary" or lead to a law's being incapable of application. ${ }^{257}$ No law has ever fallen foul of this. Clearly "arbitrariness," whatever it means, ${ }^{258}$ cannot be constituted by a mere intention to circumnavigate the Upper House, or all divisions of bills would be arbitrary. ${ }^{259}$ The Registered Partnerships Act, while falling short of what the government wished to achieve, is not nonsensical and is clearly a law capable of being applied with the aid of state implementation legislation. ${ }^{260}$

Secondly, any holding to the contrary would mean that the Bundesrat's ability to veto bills would be greatly extended in a fashion that would go well beyond the limits set by the Basic

"The Judgment," supra note 8 at 2544 . See also Robbers, supra note 67 at 780 ; Schwab, supra note 84 at $387,398$.

"The Judgment," ibid. 8 at 2546.

Another suggested source of federal power was power with respect to civil law (Art. 74(1)(I)) (Stüber, "Einleitung," supra note 38 at xxxii-xxxiv; see further Robbers, supra note 67 at 780 ).

See Pickel, supra note 2 at 257, and the dictum of McHugh J. in McNally, supra note 76.

See supra note $120 ;$ R. Scholz \& A. Uhle, "'Eingetragene Lebenspartnerschaft' und Grundgesetz" [2001] Neue Juristische Wochenschrift 393 at 394, 398; Uhle, supra note 37 at 85.

(1975) 39 BVerfGE 1 at 35; Mangoldt \& Starck, supra note 121 at 2680.

See Stüber, "Einleitung," supra note 38 at xxxiii on whether the Court itself has ever suggested this (see also (1975) 39 BVerfGE 1 at 35).

"The Judgment," supra note 8 at 2546; Staber, "Einleitung," supra note 38 at xxxiii.

Freytag, supra note 74 at 446.

Mangoldt \& Starck, supra note 121 at 2680.

(2001) 104 BVerfGE 51 at 56f; "The Judgment," supra note 8 at 2546; Freytag, supra note 74 at 446. 
Law - seriously disturbing the balance between the two Houses laid down by the Basic Law. The case law to date indicates that the inclusion of a single line in a bill subject to the Bundesrat's veto makes the whole bill subject to the veto. ${ }^{261}$ Therefore, a requirement to include such items in bills not otherwise subject to the veto - assuming it could be effectively enforced ${ }^{262}$ - would significantly enlarge the Bundesrat's de facto powers to block bills, including rules over which it is not supposed to have any power at all. Consequently, the Court rightly rejected the arguments advanced under this heading.

\section{Amendments to the LaW After its ApProval by Parliament}

For the above noted reasons, when dividing the proposed law into two, it was necessary to remove all provisions conferring new powers on state officials. Given the ease with which this task could be carried out on a word processor, it is somewhat extraordinary that in the provisions dealing with the surnames of parties after the dissolution of a registered partnership, the first of the two divided bills - which was not supposed to confer new powers on State officials - contained two provisions in s. 3(3) and (4) that conferred powers on the Registry Office, a state institution. ${ }^{263}$ It seems that no one, including the opposition and the Bundesrat when confirming that the bill was not subject to its veto, noticed this until the bill had been passed by the Lower House, the Bundesrat had decided not to engage the constitutional mechanism for objecting to bills that it cannot veto and the bill was being prepared for the Federal President's signature as the Registered Partnerships Act.

In this situation, the Common Procedural Rules for Federal Ministries ${ }^{264}$ were mobilized. Section 61 of the Rules states that the responsible federal ministry may correct "printer's errors and other obvious mistakes" and provides that "after the law has been passed" by Parliament, the consent of the Presidents of the two Houses of Parliament must be obtained for such corrections. This procedure was followed, and the two Presidents gave their consent to the removal of the offending references to the Registry Office. The consent was perhaps a formality, given that the two Presidents were members of the Social Democrats (the main governing party); ${ }^{265}$ but as the Court noted in its decision, ${ }^{266}$ the opposition parties did not object to the alteration upon being informed of it.

The Common Procedural Rules for Federal Ministries are laid down by the federal Cabinet. It is somewhat surprising to find that they purport to enable the amendment of a law after it has been passed by Parliament. While this is a frank acknowledgment of the fact that

See supra note 121 and accompanying text.

No doubt, if there were such a requirement, the government would be clever enough not to introduce bills that might require division, but would instead introduce bills not needing division. Who is then to say whether it has left out things that it should have put into such a bill?

See Bundestag, Drucksache $14 / 4545$ at 5.

[2000] Gemeinsames Ministerialblatt 526 (a consolidation of earlier versions) [Rules].

The President of the Bundesrat at the time was Kurt Beck, Premier of the State of Rhineland-Palatinate. It was not inevitable that the Bundesrat should have a President from the governing party, as convention decrees that this post is rotated among the State Premiers. The convention relating to the President of the Lower House is that he or she is appointed by the largest party. This is very often the governing party, although if an Opposition party is larger than each individual party in the governing coalition, it need not be so.

"The Judgment," supra note 8 at 2545. 
most laws emerge from the government and the bureaucracy, where this power derives from is quite unclear. Nevertheless, case law ${ }^{267}$ had previously given the green light to this procedure, the Court adding that it would perhaps be better if the procedure received express statutory authorization - a comment with which it is difficult to disagree. The Court followed suit in the case at hand, holding that the amendments concerned were "obvious mistakes" and could thus be corrected to reflect what the legislature had intended to say. ${ }^{268}$

There is some cause for unease here. Not only is the whole procedure of amending a law after it has been passed by Parliament questionable, but little was said to indicate precisely what is meant by "obvious mistakes," other than that they can appear from all the circumstances. ${ }^{269}$ However, the fact that the opposition parties agreed to the amendment is not only testimony to their sense of fair play, but also tends to reduce the level of unease that one might otherwise feel. On a practical level, an unobjectionable, if time-consuming, solution to such problems is simple to perceive: it would be easy for the Lower House to repeal the law containing the mistakes and enact a new, mistake-free one. The Common Procedural Rules for Federal Ministries merely enable the circumvention of this somewhat long-winded process. Accordingly, the Court's decision in this case deserves approval, even if it is regrettable that it will further reduce the incentive to put this process on a proper statutory footing, as previously suggested; also, a clearer definition of "obvious mistakes" may have assisted in this process.

\section{Protection OF MARRIAGe: ARTICle 6(1) OF THE REGISTERED PARTNERSHIPS ACT}

This is by far the most important heading under which the challenge to the Registered Partnerships Act was conducted. As discussed, the Court rejected the challenge by five votes to three; no other objection to the law produced such dissension.

Article $6(1)$ of the Basic Law provides simply that "marriage and the family enjoy the special protection of the state." ${ }^{270}$ It is a provision that has existed unchanged since the Basic Law came into force in 1949. It is settled law that this provision, which is contained in the basic rights section of the Basic Law, has three aspects: first, a guarantee of the existence of the legal institution of marriage which cannot therefore be abolished except by constitutional amendment; ${ }^{271}$ second, a basic right of married persons against discrimination or other disadvantageous treatment on the basis of marriage; and third, but somewhat less definitely, the provision indicates that the system of values to which the state subscribes looks favourably on the institution of marriage, which must be promoted within the legal system (this may be called a principle of state policy). This last aspect may prevent, for example, discrimination against married persons other than that imposed by the state. ${ }^{272}$ Despite the

(1964) 18 BVerfGE 1 at $18 \mathrm{ff}$.

"The Judgment," supra note 8 at $2544 \mathrm{ff}$. See also Robbers, supra note 67 at $780 \mathrm{ff}$.

"The Judgment," ibid. at 2545.

Basic Law, supra note 9.

"The Judgment," supra note 8 at 2548

On these three functions, see (1957) 6 BVerfGE 55 at 71f; (1984) 67 BVerfGE 186; (1990) 82

BVerfGE 6 at 15; Badura in T. Maunz \& G. Dürig, Grundgesetzkommentar (Munich: 37th issue, C.H. Beck, August 2000) at 44; J. Braun, "Das Lebenspartnerschaftsgesetz auf dem Prufstand - BVerfG, 
statement during the debates on the draft of the Basic Law that Art. 6(1) protects only marriage, not "concubinage," 273 it is, as we have seen, also settled law that forms of living together outside marriage are protected by the general freedom of action guaranteed by Art. 2(1). However, Art. 6(1) goes beyond this and promises "special" protection. ${ }^{274}$ As mentioned earlier, "marriage" in Art. 6(1) is understood to mean monogamous heterosexual marriage, and as yet there are no signs of that changing. ${ }^{275}$

Let us now consider the new legal institution of the registered partnership under the three aspects of the guarantee contained in Art. 6(1), ${ }^{276}$ starting with the guarantee of the continued existence of marriage as an institution. The glories of the institution of marriage unleashed a flood of rhetoric from the opponents of registered same-sex partnerships on the importance of protecting marriage as the best institution for the upbringing of children, the need for many children if the state is to continue to exist, and the fact that homosexuals cannot procreate. ${ }^{277}$ However, as a Canadian commentator said in relation to similar debates in that country, the argument "is so flimsy that it is astonishing how often it appears."278 It is not clear that marriage and its constitutional protection exist solely for the purpose of giving a home to numerous children: infertile couples can marry, as can those not intending to have children. ${ }^{279}$ Further, Art. 6(1) mentions "marriage and the family" separately, not "marriage leading to a family." ${ }^{280}$ Of course, it is possible to derive from that constitutional collocation some sort

NJW 2002, 2543" [2003] Juristische Schulung 21 at 21 ["Prüfstand"]; Burgi, supra note 62 at 495-97; Krings, supra note 63 at 411 ; Michalowski \& Woods, supra note 72 at 245f; Schimmel \& Heun, supra note 8 at 577; Schluter, Heckes \& Stommel, supra note 17 at 8 ; B. Schmidt-Bleibtreu \& F. Klein, Kommentar zum Grundgesetz, 9th ed. (Neuwied: Luchterhand, 1999) at 240; Scholz \& Uhle, supra note 254 at $396 \mathrm{ff}$; Trimbach, supra note 74 at 65. Quoted in J. Wasmuth, "Zur Verfassungsmaßigkeit der eingetragenen Lebenspartnerschaft" [2002] Der Staat 47 at 54 ["Verfassungsmäßigkeit"].

Risse, supra note 16 at $246 \mathrm{ff}$, pointed out that special protection assumes that other ways of life still receive the normal level of protection.

The Court's decision (supra note 8 at 2547) adhered to the line of reasoning that marriage is the union of a man and a woman.

276 Notice that no consideration is given to the question of whether the protection of the family may have assisted in validating the law, a homosexual couple being seen as a family for this purpose ( $c f$. cases such as Fitzpatrick v. Sterling Housing Association, [2001] 1 AC 27 (H.L.). For a similar unreported admissibility decision from Austria before the European Court of Human Rights, see Karner v. Austria (11 September 2001), 40016/98 (E.C.H.R.)). This view does not appear to have been argued by any commentator in Germany. The reason is probably that homosexual couples cannot be said to be part of the same family unless the Registered Partnerships Act is first held to be valid, as s. 11(1) of the Act makes registered partners members of the same family. For further references to European law on this topic, see Aidan O'Neill, "Fundamental Rights and the Constitutional Supremacy of Community Law in the United Kingdom after Devolution and the Human Rights Act" [2002] P.L. 724, 729, n. 17.

"The Judgment," supra note 8 at 2552 (dissenting judgment); J. Braun, "Gleichgeschlechtliche Partnerschaft und Ehe" [2001] Zeitschrift fur Rechtspolitik 14 at $16 \mathrm{ff}$; Braun, "Ein neues," supra note 5 at 25; P. Kirchhof, "Lebenspartnerschaftsgesetze und Grundgesetz" [2001] Familie, Partnerschaft, Recht 436 at 438; Scholz \& Uhle, supra note 254 at 393; Uhle, supra note 37 at $91 \mathrm{ff}$. MacDougall, supra note 2 at 249.

Bruns, "Art. 6(1)GG," supra note 16 at $6 \mathrm{ff}$; Klein, supra note 6 at 435 ; Schimmel \& Heun, supra note 8 at 579; Stüber, "Einleitung,"supra note 38 at xxxviii. See also the amusing account in M. Freeman, "United Kingdom Law and the Gay, with Special Reference to Gay Marriages" in Basedow et al., eds., supra note 16 at 179. 
of connection between marriage and the family, or to argue that marriage is protected because it typically, although not always, produces children. ${ }^{281}$ However, the argument is not quite as convincing as it was under the Constitution of the Weimar Republic, ${ }^{282}$ which expressly stated that marriage was protected because it is the institution that guarantees reproduction and, thus, the continuance of the state. ${ }^{283}$ Nor can it be said that marriage exists solely to carry out functions that homosexuals cannot: it performs other services to society that homosexual partnerships can also perform, such as channelling the sexual impulse, reducing the burden on the social security system by requiring partners to support each other, and providing, at least in some cases, a system of support and social stability ${ }^{284}$ that may include children brought up by same-sex partners. ${ }^{285}$ Quite possibly, the real threat to the institution of marriage comes not from same-sex partners, but from people who could marry but prefer to live in a de facto heterosexual relationship. ${ }^{286}$ Therefore, it requires some imagination - or prejudice against homosexuals - to see the institution of registered partnership as a "Trojan horse" ${ }^{287}$ designed to undermine the institution of marriage, the fecundity of the population and, thus, the continued existence of the state.

The Court was able to dismiss arguments based on the need to protect the institution of marriage with the simple yet convincing point that the institution of marriage is in no way affected by registered partnership, nor is anyone's freedom to marry affected. ${ }^{288}$ The alleged need for the state to continue to support, and to support exclusively, an institution that ensures the production of children in order to secure its continued existence clearly did not impress the judges. It need only be added that the fact that a legal institution has been created for gays and lesbians that serves many of the same goals as marriage, but is not called marriage, only underlines the uniqueness of the institution of marriage in society. ${ }^{289}$

Equally, there was little hope of having the law invalidated under the second aspect of Art. $6(1)$, as it did not discriminate against married people ${ }^{290}$ or otherwise interfere with their

As do the authors cited, supra note 277; Krings, supra note 62 at 410 ; W. Pauly, "Sperrwirkungen des verfassungsrechtlichen Ehebegriffs" [1997] Neue Juristische Wochenschrift 1955 at 1955; Zimmermann, supra note 5 at 651,661 .

Art. 119(1).

See e.g. Trimbach, supra note 74 at 66.

Quilter, supra note 64 at 534; Freytag, supra note 74 at $450 \mathrm{ff}$; Schimmel \& Heun, supra note 8 at 578; Stüber, "Einleitung," supra note 38 at xxxviiif; Stüber, "Gleichstellung," supra note 5 at $597 \mathrm{ff}$; Trimbach, supra note 5 at 401.

Wasmuth, "Verfassungsmaßigkeit," supra note 273 at 49.

Krause, supra note 22 at 209; Sachs, supra note 5 at 49; Scherpe, "Zehn Jahre," supra note 16 at 36; Trimbach, supra note 74 at 66 .

Braun, "Prufstand," supra note 5 at 30.

"The Judgment," supra note 8 at $2547 \mathrm{ff}$; one of the chief opponents of the law agrees (Braun, "Prüfstand," supra note 272 at 21). See also Burgi, supra note 62 at 496; Freytag, supra note 74 at 448; Lautmann, supra note 34 at 102; Sachs, supra note 5 at 48; Stuber, "Einleitung," supra note 38 at xxxv. Robbers, supra note 67 at 783; Zimmermann, supra note 5 at $654 \mathrm{ff}$.

Except in one respect, by not subjecting registered partners to the income cumulation for certain social security purposes, to which spouses are subject. This was in the Supplementary Bill, which those opposed to registered partnerships prevented from being passed. The Court's view appears to be that the non-subjection of registered partners to income cumulation may be constitutionally invalid ("The Judgment," supra note 8 at 2548). See further Maria S. Augstein in Bruns \& Kemper, supra note 38 at $505 \mathrm{ff}$; Kiel, supra note 73 at 495-97; Muscheler, supra note 23 at 47; Schwonberg, "starkt Ehe," supra note 128 at 229; Schwonberg, "Eingetragene," supra note 103 at 56; and on the status of income tax deductions, "The Judgment," supra note 8 at 2551. Muscheler, supra note 23 at 231, is of the view 
existing rights. ${ }^{291}$ Little more could be expected from Art. 6(1) as a principle of state policy. The only argument that could be put forward under this heading was that bisexual people would no longer have a preferred option - marriage - presented to them by the state, ${ }^{292}$ and that the "normality"293 of heterosexuality would be diluted by the creation of a legal institution for same-sex partners. These statements were not generally dignified with a response; while one author pointed out that such effects would hardly be measurable, ${ }^{294}$ another pointed out that these fears appear to exaggerate the seductive power of homosexuality for the average heterosexual, ${ }^{295}$ and a third pointed out how comical it is that the defenders of heterosexual marriage are reduced to mobilizing bisexuality for their purposes. ${ }^{296}$ Unlike one author, who thought that the argument was about as sensible as arguing that banning mosques would increase the number of churchgoers, ${ }^{297}$ the Court confined itself to stating that marriage was not threatened by an institution addressed to people who cannot marry each other. ${ }^{298}$

Given the somewhat bleak situation for opponents of the law, ${ }^{299}$ they were reduced to inventing new doctrine, namely, a command allegedly inherent in Art. 6(1) to treat marriage more favourably than all other forms of living together and to avoid creating an institution that is a copy of marriage.$^{300}$ The argument was doomed to fail on the ground that its minor premise is false: the Registered Partnerships Act does not treat registered partners as favourably as spouses, nor is it a copy of marriage. The major premise of the argument had not been previously enunciated in the case law. ${ }^{301}$ However, this may be simply because the occasion to do so had not yet arisen. The alleged command was said to flow either from the word "special" in Art. 6(1), or as a necessary reverse implication from the commands to promote marriage, or not to disadvantage marriage.

that the failure of the Registered Partnerships Act to provide that the obligation to make postpartnership support payments can be triggered only at the occurrence of certain events connected with the former relationship (which connection is required for former spouses: see e.g. Civil Code, s. 1572) is a further respect in which (former) registered partners are advantaged as against married persons. However, this will not be so from the point of view of the former partner making the payment, and the other differences between post-nuptial and post-partnership support cancel this out. Bruns, "Art. 6(1)GG," supra note 16 at 8; Freytag, supra note 74 at 446; Wasmuth, "Verfassungsmäßigkeit," supra note 273 at 58 ; Zimmermann, supra note 5 at 654 .

Braun, "Ein neues," supra note 4 at 59. A more reflective point made by Professor Braun along the same lines is that this conclusion is connected to the view that sexual orientation is not chosen by person, which may not necessarily be true in all cases (Prüfstand," supra note 272 at 24). Braun, "Ein neues," supra note 5 at 27.

Robbers, supra note 67 at 782.

Bruns, "Art. 6(1)GG," supra note 16 at 7.

Muscheler, supra note 23 at 61 . See also the more serious response by M. Bruns, "Erwiderung" [2002] Juristenzeitung 291 at 294 ["Erwiderung"].

Muscheler, supra note 23 at 43. See also Sachs, supra note 5 at 48f; Wasmuth, "Verfassungsmäßigkeit," supra note 273 at 58; Zimmermann, supra note 5 at 655-57.

"The Judgment," supra note 8 at 2548.

Moreover, similar arguments have been rejected in England: Fitzpatrick v. Sterling Housing Association, [2001] 1 A.C. 27, 40. See also Mendoza v. Ghaidan [2002] 4 All E.R. 1162 at para. 25 (C.A.).

As their major premise, this view was expressed by different authors in slightly different ways: see Burgi, supra note 62 at 502; Krings, supra note 63 at $412-14$; Robbers, supra note 67 at 783 ; Scholz \& Uhle, supra note 255 at 398 ; Uhle, supra note 37 at 90 . On the inability to agree on the precise wording of the alleged command, see Stuber, "Einleitung," supra note 38 at xxxvi. 
It was on this point that the Court divided five to three. The majority held that the authorization given by Art. 6(1) to the legislature, to place marriage on a more favourable footing than other forms of living together in order to do justice to its function as a principle of state policy as well as to promote the institution, could not be turned into a command to disadvantage all other forms of living together. This was at least the case when those other forms "do not compete with marriage as a bond between different-sex partners." ${ }^{302}$ Neither the words of the provision nor its history supported such a reading. ${ }^{303}$ At first glance, the Court based its reasoning on the view that the registered partnership, not being open to heterosexuals, does not compete with marriage and therefore could be afforded equal status with marriage. The minority held that (as Mr. Justice Papier put it) the institution of marriage was not protected in name only, but that the legislature was also prevented from creating an equivalent, merely differently named, institution for same-sex partners "with otherwise corresponding rights and duties"304 — and that the majority had failed to consider whether this had occurred in the case at hand.

The reason for the majority's non-consideration of this point should be apparent from their differing assumptions as to the requirements of Art. 6(1). It was, Mr. Justice Papier, dissenting, continued, an error to state that the same-sex registered partnerships law could not compete with marriage and detract from its constitutionally-mandated uniqueness as an institution simply because its addressees were different, namely homosexuals and heterosexuals. ${ }^{305}$ Madam Justice Haas effectively agreed with this, ${ }^{306}$ and held that special protection for marriage meant creating privileges for marriage that are not available to any other institution in society. ${ }^{307}$ However, none of the minority examined the Registered Partnerships Act in any detail to substantiate the claim that it created an institution with the same rights and duties as marriage - which clearly it does not. Nor are we told at what point the difference between marriage and other institutions would be great enough to satisfy Art. $6(1)$; there was no indication that the dissenting Justices thought that the existence of the institution of registered partnership was in itself offensive to Art. 6(1).

For this reason, at least, the minority's view must be rejected. ${ }^{308}$ That still leaves the question whether the situation would be different if the Supplementary Bill were passed. The registered partnership would then be much closer to marriage in the rights and duties it creates, although some points of difference would remain, such as the lack of an obligation to "live in a marital relationship" and the lack of provisions for joint adoption of children. ${ }^{309}$

"The Judgment," supra note 8 at 2548-49; Bruns, "Art. 6(1)GG," supra note 16 at 8; Wasmuth, "Verfassungsmäßigkeit," supra note 273 at 65 ; Zimmermann, supra note 5 at $656 \mathrm{ff}$.

"The Judgment," ibid. at 2548ff.

Ibid. at 2551; see also Braun, "Familie," supra note 4 at 61 .

"The Judgment," supra note 8 at 2551.

Ibid. at 2552.

Ibid. at 2551 .

Robbers, supra note 67 at 784; Stuber, "Einleitung," supra note 38 at xxxv, xl-xliv. An odd example to the contrary is Kaiser, supra note103 at 624. Uhle (supra note 37) came to the conclusion that the registered partnership was equal to marriage, but only by adopting the unarguable view that the division into two bills was unconstitutional and by counting the provisions of both together. See also Scholz \& Uhle, supra note 255 at $394,398$.

Minor differences, such as the different basic assumption relating to joint surnames, may be thought to be de minimis and mere differences in nomenclature, such as divorce/dissolution, should be entirely disregarded. To this extent, the opponents of the Bill are correct: see Braun, "Familie," supra note 4 at 
The majority appear to be ready to accept this, given their emphasis on the non-competition between institutions designed for two different groups: homosexuals and heterosexuals. Would this still be in accordance with the "special" 1310 protection that Art. 6(1) grants to marriage? What would be special about an institution of which a near-mirror image is found in other legislation? $?^{311}$

One might reply that the "special" thing about marriage is the same as it has always been: marriage is the only state-recognized institution for heterosexual partnership leading, in many cases, to the foundation of a family. ${ }^{312}$ It is the only such institution that enjoys constitutional protection and cannot be abolished without a constitutional amendment. ${ }^{313}$ Further, it may be said that "special" does not mean "exclusive" protection, ${ }^{314}$ and that an almost similar institution for same-sex couples is therefore in order. ${ }^{315}$ At all events, arguments such as these, building on the majority's reasoning, are likely to be well-received should they ever need to be made. ${ }^{316}$ Moreover, the Court itself appears to believe that less weight should be attached to the word "special," given its somewhat chequered history in the drafting of the Basic Law. ${ }^{317}$ Much more questionable, given the Court's emphasis on the fact that the Registered Partnerships Act did not compete for the same clientele as marriage, is whether an institution similar to the registered partnership could be created for heterosexuals. ${ }^{318}$ Therefore, the same-sex registered partnership owes its clear validity to the fact that, as it includes only homosexuals, it is recognizably not marriage and, therefore, is likely to remain what may be called a "straight-free zone."

\section{E. Equality}

It is somewhat surprising that a law designed to end, or to reduce, a long-standing inequality should be attacked because it fails to provide for equality. However, this is merely the result of the extreme broadness of the principle that "all people are equal before the law," as Art. 3(1) of the Basic Law expresses itself. ${ }^{319}$ Depending on the points of comparison,

61; Braun, "Ein neues," supra note 5 at 26ff; Scholz \& Uhle, supra note 255 at 397 ; Uhle, supra note 37 at 89.

$310 \quad$ See also Zimmermann, supra note 5 at 656.

311 R. Zippelius, "Verfassungsgarantie und sozialer Wandel - das Beispiel von Ehe und Familie" [1986] Die offentliche Verwaltung 805 at $808 \mathrm{ff}$.

312 Zimmermann, supra note 5 at 656 . For a slightly broader view: Stuber, "Gleichstellung," supra note 5 at $596 \mathrm{ff}$.

313 Braun, "Prufstand," supra note 272 at 22.

314 Despite arguments from the usual suspects to the contrary: Scholz \& Uhle, supra note 255 at 397; Uhle, supra note 37 at 85 . See also Pauly, supra note 281 at 1956.

315 Freytag, supra note 74 at 449; Stuber, "Einleitung," supra note 38 at xxxvi; see also Burgi, supra note 62 at 502.

316 In any event, this is the conclusion reached by a prominent opponent of the law (Braun, "Prufstand," supra note 272 at 23 ).

317 See "The Judgment," supra note 8 at 2549 , where it was suggested that "special" was inserted for reasons of euphony only. See also Freytag, supra note 74 at 449; Krings, supra note 63 at $411 ; c f$. Ott, supra note 67 at 117 (rejecting relevance of drafting history).

318 See also (1990) 82 BVerfGE 6 at 15 (no requirement to refuse entirely to recognize de facto relationships); "The Judgment," supra note 8 at 2549f; Battes, supra note 110 at 118 ; Pauly, supra note 281 at 1956; Robbers, supra note 67 at 783; Schwonberg, "stärkt Ehe," supra note 128 at 228. not sexual orientation. It was the basis for the first objection to the Act under this heading. 
some arguable case of inequality can almost always be shown. After all, every law discriminates between those to whom it applies and those to whom it does not. Crucial, therefore, is the selection of the base groups for comparison - that is, who is or is not equal with whom? - and the question of whether the differences between the groups thus compared can be justified, having regard to the differences between them. There was nothing new in the case at hand on the applicable doctrine in such cases. The test adopted by the German Federal Constitutional Court has long been settled: whether "one group of persons to whom a rule of law is addressed is treated differently from another such group, although there are no differences of such a type and such a degree as would justify the unequal treatment." ${ }^{320}$ In rejecting inequality-based arguments raised in the case at hand, the Court either denied that unequal treatment was present at all or, if that was found to be impossible, based its view on the second arm of that test relating to the justification of unequal treatment; in doing so, the Court found that differences existed which justified unequal treatment. The Court was aided in its task by the principle that the legislature is allowed to leave some inequality in the system if it is necessary to deal with groups having regard to their typical characteristics, which may not be present in every case. ${ }^{321}$

The Court summarily rejected three objections ${ }^{322}$ under the heading of equality. First, the Court denied that the Registered Partnerships Act discriminated on the basis of sex by not allowing people of different sexes to enter into a registered partnership: a woman who wished to enter into a partnership with a man is not permitted to do so, whereas it is permissible for a man. The Court held that this was not a case of discrimination as people of each sex were free to enter into a registered partnership with people of the same sex. ${ }^{323}$ In relation to marriage, there has been a similar debate - as Canadian readers know only too well - as to whether, despite the fact that the two sexes are treated in the same way, such that individuals are able to marry only members of the opposite sex, marriage discriminates on the basis of sex; the question arises since a man wishing to marry another man could do so if he were in exactly the same position yet female, and vice versa. ${ }^{324}$ Unsurprisingly, given that the paradox involved seems incapable of resolution by rational means, the Court showed no awareness of such debate. ${ }^{325}$

See e.g. (1998) 99 BVerfGE 129 at 139. This test is restated in the case at hand ("The Judgment," supra note 8 at 2549). See further standard textbooks such as B. Pieroth \& B. Schlink, Grundrechte: Staatsrecht II, 17th ed. (Heidelberg: C.F. Muller, 2001) at 102-104 and English-language summaries such as Michalowski \& Woods, supra note 72, c. 10.

$321 \quad$ See e.g. (1992) 87 BVerfGE 234 at 267.

322 For a dismissal of other possible objections, see Freytag, supra note 74 at 453 . See also Sachs, supra note 5 at 50; Wasmuth, "VerfassungsmäBigkeit," supra note 273 at 69.

"The Judgment," supra note 8 at 2549. See also Robbers, supra note 67 at 785; cf. Sachs, ibid. at 50; Sarantakos, supra note 28 at 81 .

324 For the debate in other countries, see the U.S. case of Brause v. Bureau of Vital Statistics, [1998] WL 88743 at 6 (Alaska Super. Ct.) (WL); Quilter, supra note 64 at 535-38; Braun, "Prufstand," supra note 272 at $24 \mathrm{ff}$; Krings, supra note 63 at $410 \mathrm{f}$; Lundmark, supra note 22 at 238, 241; Sachs, supra note 5 at 46; Strick, supra note 40 at $84-86$; Stuber, "Einleitung," supra note 38 at xxxii; Sunstein, supra note 22 at $198-208$.

Which is not particularly relevant in Germany, for if this situation constitutes discrimination, it is justified by Art. 6(1) as an exception to Art. 3(1): Sachs, supra note 5 at 47; Strick, supra note 40 at 85; Stüber, "Einleitung," supra note 38 at xxxii. 
Opponents also argued that it was discriminatory to prohibit different-sex partners, rather than individuals, from entering into a registered partnership. This argument was made under the general equality provision of Art. 3(1), and so discrimination on the basis of sex was no longer relevant. The Court held that the unequal treatment involved in excluding different-sex partners from registration was justified by the possibility that such persons may produce children and by the fact that they can marry. ${ }^{326}$ Finally, it was argued that the failure to open registered partnerships to siblings and other close relatives constituted discrimination against these groups. ${ }^{327}$ This was rejected on the ground that siblings "often" 328 are part of wider networks of support and, moreover, already receive some indulgence from the law in the area of inheritance and rights to refuse to testify against each other. Therefore, the unequal treatment was said to be justified.

Dissenting on this last point, Madam Justice Haas held that the majority had failed to provide sufficient reasoning to justify its view and had taken refuge in generalities. ${ }^{329}$ There is probably something to this, even allowing for the fact that generalities are permitted to some extent in determining whether unequal treatment exists or is justified. This author would find fault, rather, in the width and generality of the requirement in Art. 3(1) not to treat people unequally. Even accepting that requirement, however, the Court might have added to its reasons. Thus, it might have pointed out that excluding different-sex partners from registered partnership prevents the even greater inequality that would arise if heterosexuals had a choice between marriage and registered partnership while homosexuals did not. Therefore, registered partnership should be seen as a means of redressing the inequality in not providing a legal institution for homosexuals, ${ }^{330}$ not as a means of disadvantaging a group that was already advantaged. ${ }^{331}$ Further, rather than speculating about the networks of support available to siblings, it may have been better to acknowledge that the registered partnership, whatever the law might strictly say, was designed for a sexual relationship and to point to the equivalent prohibitions in the law of marriage.

It was, in any event, unlikely that the majority Justices would seize on any of the inequality points to invalidate a law of which they clearly approved. ${ }^{332}$ A more striking example of reasoning from the desired conclusion is provided by two academic opponents of the law. ${ }^{333}$ Their view reduces to the position that if the Registered Partnerships Act equated registered partnerships with marriage it was invalid under Art. 6(1); if not, the differences between same-sex and different-sex partners invalidated the law under Art. 3(1). Such

326 "The Judgment," supra note 8 at 2550; Dethloff, supra note 25 at $2598 \mathrm{ff}$; Stuber, ibid. at xlv; Zimmermann, supra note 5 at $661 \mathrm{ff}$; contra Krings, supra note 63 at 414 . Cf. also Freytag, supra note 74 at 454.

Scholz \& Uhle, supra note 255 at 400 . For arguments against this view, see Freytag, ibid. at 454; Robbers, supra note 67 at 785; Stüber, ibid. at xlv; Wasmuth, "Verfassungsmäßigkeit," supra note 273 at 70 (pointing out that this argument would also lead to the invalidity of the equivalent provision in the law of marriage).

$328 \quad$ "The Judgment," supra note 8 at 2550.

329 Ibid. at 2552; see also Uhle, supra note 37 at $90 \mathrm{ff}$.

330 As the Court did in fact do when deciding the application for an interlocutory injunction against the law (see text accompanying supra note 109).

331 Boele-Woelki \& Schrama, supra note 20 at 59, 70f; Krause, supra note 22 at 216; Stuber, "Gleichstellung," supra note 5 at 599.

332 See supra note 105.

333 Braun, "Prüfstand," supra note 272 at $25 \mathrm{ff}$; Scholz \& Uhle, supra note 254 at 399. 
overdetermination of the outcome and incapacitation of the legislature by a thicket of constitutional rights clearly had to be avoided.

Fortunately, perhaps, in terms of the coherence of the Court's reasons, there was no discussion of other possible forms of discrimination to which the law gives rise, such as its failure to provide comprehensively for polygamy (even if "bi-bigamy" is possible, there is no such provision for persons who are all of the same sex). ${ }^{334}$ However, the Court did reject one final argument to the effect that the limited rights to care for one's registered partner's child provided by s. 9 of the Registered Partnerships Act disadvantaged de facto partners, for example, on whom the law confers no such rights. The Court held that they could take steps to have those rights awarded to them that the law now confers on same-sex partners. ${ }^{335}$

\section{F. Miscellaneous}

The Court dealt briefly with other minor objections to the law which, at most, could have had the effect of invalidating parts of the law. ${ }^{336}$ The claim that the limited right to care for one's registered partner's child (conferred by s. 9) breached the right of non-custodial parents to bring up their children (Art. 6(2) of the Basic Law) was easily met by the principle that the right is subject to the broad capacity of the legislature to shape its precise content in the dayto-day law. Furthermore, any non-custodial parent must have had custody refused or withdrawn by some legal rule other than s. $9 .{ }^{337}$ Nor did alterations to the law of inheritance in favour of registered partners infringe the guarantee of that right in Art. 14(1), as the new rights were justifiable having regard to the creation of the new legal institution of registered partnership. ${ }^{338}$

\section{Conclusion}

As of July 2002, slightly less than a year after the Act came into force, the number of registered partnerships was not very great. At that time, the news magazine Stern conducted a survey in the larger German cities and found that 3,146 partnerships had been registered: 2,410 of the partnerships involved men and 736 involved women. On that basis, the magazine estimated that about 4,500 registered partnerships existed throughout Germany, or about 1 percent of the number of marriages contracted in a year. ${ }^{339}$ Of course, it is possible that some would-be partners waited for the law to be upheld by the court. It is also possible that some sped up their "wedding day" lest the law should be subsequently invalidated. However, given that there must have been some element of pent-up demand for this new legal institution, it can hardly be said that the take-up rate has been surprisingly high.

Krause, supra note 22 at 215 ; Sachs, supra note 5 at 49 ; Stüber, "Einleitung," supra note 38 at xlv; Verschraegen, supra note 20 at 74.

"The Judgment," supra note 8 at 2550.

See also Zimmermann, supra note 5 at $663 \mathrm{ff}$.

"The Judgment," supra note 8 at 2550.

Ibid. at $2550 \mathrm{ff}$; see also Leipold, supra note 166 at 222; Stüber, "Einleitung," supra note 38 at xlv-xlvii. Stern (Hamburg) (11 July 2002) 23. Dr. Meyer of the Federal Ministry of Justice has informed the author that no statistics are kept there, and if statistics were kept elsewhere (e.g., by the State governments), it may be expected that Stern would have referred to them. 
Among those partners who have registered, each couple will have had its own reasons for deciding to take advantage of the new law. Some will have welcomed the opportunity to have the state recognize a partnership, possibly one of many years' or even decades' standing, and to "make it official",340 others will have placed more emphasis on the tangible benefits offered by the law. ${ }^{341}$ However, the Registered Partnerships Act falls short of the ideal in both respects. Returning to the five criteria mentioned at the outset, the extent to which the law provides a ceremony fulfilling the need for a public affirmation of a partnership will depend on the rules adopted in each state to determine the form of the ceremony and the "responsible authority." In this respect, the "normal" means of affirming a partnership at the Registry Office, as adopted in most states, is superior to the Bavarian solution of a ceremony before a notary public, as the former most closely approximates the full ceremonial performance of marriage ${ }^{342}$ It is interesting to note that in the Stern survey, Bavaria's capital, Munich, had the ninth-highest per-person rate of "partnering" in Germany, while the next two Bavarian cities on the list, Regensburg and Würzburg, were 21st and 22nd respectively. Of course, it is not possible to know whether the Bavarian solution had any influence on this, or whether it is due more generally to Bavarian conservatism. ${ }^{343}$

Second, it is obvious that the Registered Partnerships Act is an incomplete work so long as the Supplementary Bill remains unpassed. The Act as it stands does not offer the same range of tangible benefits as marriage, and the omissions - with the exception of the nonavailability of joint adoption and the lack of a formal obligation to live together - have a somewhat random character. As such, they are explicable not by a decision based on the merits of the matter, but on the basis of rules of constitutional law. ${ }^{344}$

Although the precise rules of constitutional law in Canada are very different and the Canadian government's proposal is for legislation to recognize gay marriage rather than to create a separate institution, similar difficulties may occur owing to the inability of the federal legislature to regulate the subject matters listed in ss. 92(12) and (13) of the Constitution Act, $1867^{345}$ and the resulting possibility of divergence among the provinces. However, it is worth noting that any provincial legislation that, following the Bavarian model, seeks to provide a different ceremony or celebrant for same-sex marriages from that prescribed for heterosexuals would not only have to run the gauntlet of being tested for validity under s. 92(12), but would also be subject to review under the equality provisions of the Canadian Charter of Rights and Freedoms. ${ }^{346}$ This problem did not exist in Germany, given that the states were acting under federal legislation that was upheld as valid despite the inequalities created between heterosexual and homosexual unions. One wonders whether any province proposing such legislation would dare to argue that its legislation provides for a "separate but equal" ceremony for gays and lesbians.

Bruns, "Erwiderung," supra note 296 at 294.

Christensen, supra note 16 at 1745.

See also MacDougall, supra note 2 at 238, 260-64, arguing that only marriage will do as a public, statesponsored affirmation.

Peschel-Gutzeit, supra note 105 at 433 identified a division between north and south Germany in attitudes to the registered partnership.

von Dickhuth-Harrach, supra note 191 at 1670.

Supra note 11.

Supra note 13. 
Even if the Supplementary Bill is passed, the continued lack of joint adoption rights is likely to prove a significant gap in the Act, especially for lesbians, and will deter some partners from taking on the duties associated with registered partnership in return for the proferred package of rights. ${ }^{347}$ One might well ask, "Why should lesbian and gay couples have to settle for an inferior marriage mark two?"348 Even if there are good reasons for calling the homosexual partnership something other than marriage, or that course is required constitutionally (a matter which cannot be determined on the basis of current case law), the reasons given for endowing registered partnership with fewer rights do not stand up to scrutiny. The only possible exception is the case in which rights are less extensive because responsibilities are justifiably, or at least on some rational basis, also less extensive: for instance, the lesser right to post-partnership support may be thought to correlate to the less well-defined nature of the partnership while it exists.

As far as the broader societal goals of a registered partnership are concerned, the law does a reasonably good job of requiring parties to provide for each other both during and after the existence of a partnership. However, its failure to provide for income cumulation for social security purposes is not defensible. ${ }^{349}$ The mutual rights of support may be one possible reason behind the relatively low take-up rate of the registered partnership. Whether the Act will be effective in reducing prejudice against, and increasing acceptance of, homosexuals is not something that can be said with any certainty at this stage, ${ }^{350}$ although it is interesting to note that various branches of the Protestant Church, such as the Synod of the Protestant Church of Berlin and Brandenburg, decided that a church blessing would be available to registered partners in parishes prepared to conduct such a ceremony. ${ }^{351}$

Finally, the Registered Partnerships Act shares the defect common to all "opt-in" systems of providing no protection to vulnerable parties whose partners refuse to opt in. ${ }^{352}$ The corresponding advantage is that the decision about whether to claim rights and undertake obligations is left in the hands of the parties. ${ }^{353}$ This is the familiar trade-off between freedom and equality. It is also usually easy to ascertain, under an "opt-in" system, whether people have opted in, which is not the case if the existence of a de facto relationship has to be

Weiß \& Becker, supra note 33 at 111 , reporting that two-thirds of lesbians rejected any registered partnership legislation that did not include a right to adopt, a figure that was far higher than among gay men. See also ibid. at 140.

Tatchell, supra note 19 at 17.

See supra note 290 and accompanying text.

As has apparently been the case in Denmark: Scherpe, "Zehn Jahre," supra note 16 at 36 reports that a government minister appeared at a Royal banquet with his same-sex partner without any offence being caused.

Evangelischer Pressedienst, Wochenspiegel, 21 November 2002, Ausgabe Ost (Berlin) at 6; Tagesspiegel (Berlin) (17 November 2002) 10. As of January 2003, the web site of the Lesbian and Gay Association of Germany, <www.lsvd.de>, listed other constituent parts of the German Protestant Church with a similar position. Further information may also be found online: Homosexuelle und Kirche <www.huk.org>.

Muscheler, supra note 23 at $31 \mathrm{ff}$. Lautmann, supra note 34 at 103, claims that such people have so far been able to protect themselves well enough, although he provided no evidence of this.

Sarantakos, supra note 28 at 84; Scherpe, "Zehn Jahre," supra note 16 at 37. 
proven. ${ }^{354}$ An "opt-in" system can accordingly save a great deal of trouble, expense, and uncertainty when, for example, inheritance rights are at stake. ${ }^{355}$ Finally, forcing people into a legally-recognized relationship of quasi-marriage (as Alberta's law might be said to do in some circumstances) would doubtless be unacceptable to those in gay and lesbian communities who reject any form of marriage because they think that it is "too square." this regard, the German legislature has probably chosen the best of all available options, especially given that people holding such views may be prepared to enter into the looser coalition contemplated by the Registered Partnerships Act which, moreover, is characterized differently from heterosexual marriage and thus recognizes the difference between homosexuality and heterosexuality. ${ }^{357}$

As was suggested earlier, for those who do opt in, some better form of ensuring that their property rights inter se are properly regulated ought to be established. Making one form of property division which may not be appropriate for all registered partners available without legal advice is a poor solution. In particular, it falls between the two poles of making the registered partnership easy to access and making sure that it is not entered into before property questions are properly considered. It is hard to avoid the conclusion that a universal requirement of legal advice would be advantageous. This need not be expensive for lowerincome partners if a standard option can be developed for those with fewer assets, while those with more assets can afford, and should have, more detailed advice. As we have seen on a number of other points, the legislature has not thoroughly thought through its law; even supporters ${ }^{358}$ of the $A c t$ declare it to be a poor piece of legal drafting owing to the haste with which it was drafted. ${ }^{359}$

The German experience makes one rather wary of the Canadian process to date, which has been based on case law rather than comprehensive studies of the real needs of same-sex partnerships and whether or not they can be assimilated to heterosexual ones. Clearly, attention must be paid to the drafting process. Unnecessary deviations from the law of marriage should be avoided, yet the law of marriage should not be assumed to automatically apply to same-sex relationships that may have rather different characteristics from heterosexual ones. The tension here is between the easy and sometimes appropriate option of reproducing the law of marriage, and the difficult but sometimes necessary process of adapting it to a different set of circumstances. This, too, reinforces the need for study and thought about the process itself - rather than enacting laws on the run to satisfy a short-term need created by a court decision and as a result of political compromises not necessarily designed to improve the quality of legislation.

Krause, supra note 22 at 217-19; Scherpe, "Zehn Jahre," ibid. at 36ff; Schluter, Heckes \& Stommel, supra note 17 at $16 \mathrm{ff}$; Stüber, "Einleitung," supra note 38 at xxvii. Occasionally, German law recognizes de facto relationships, and thus requires their existence to be proved. See for example, the recent unreported decision of the Federal Social Court (17 October 2002), B 7 AL96/00. Schluter, Heckes \& Stommel, ibid. at 17

See Christensen, supra note 16 at $1709 \mathrm{ff}$; Sarantakos, supra note 28 at 82; Stüber, "Einleitung," supra note 38 at xxixf; Verschraegen, supra note 20 at $66,72 \mathrm{ff}$.

Lautmann, supra note 34 at 103 , $105 \mathrm{ff}$.

Muscheler, supra note 23 at 29-31. See also Battes, supra note 110 at 116; Kaiser, supra note 139 at 873; Leipold, supra note 166 at 218; Rieger, supra note 30 at 1498; Schluter, Heckes \& Stommel, supra note 17 at 17; Stuber, "Einleitung," supra note 38 at xxvii.

Battes, ibid. at 122; Schwab, supra note 84 at 387. 
Finally, it is very interesting to discover how many basic rights could be mobilized against a "progressive" measure such as registered partnerships for same-sex couples: three of eight Judges were prepared to hold that basic rights prevented the introduction of such an institution. There are lessons here for those drafting bills of rights. First, what might be called "hurrah" statements, such as the assertion that "marriage and the family enjoy the special protection of the state," should be avoided unless there is a real need for them. What gets a big cheer one decade may seem hopelessly old-fashioned the next. Constitutions do not exist to make people feel good about certain institutions or to provide lists of "things we like." Rather, they keep the institutions of government running and protect certain basic rights from infringement. Second, precision should be the aim of those drafting declarations of rights. If the objective of Art. 6(1) was to prevent discrimination against married people, it should have been stated as such. The course of German legal history would not have differed much over the last few decades even if a more precise statement, such as that suggested, had been included in the Basic Law. The principal doubts about the validity of the Registered Partnerships Act, however, would have been avoided. 